\title{
2. Social convergence of the Baltic states within the enlarged EU: Is limited social dialogue an impediment?
}

\author{
Jaan Masso, Vladyslav Soloviov, Kerly Espenberg and \\ Inta Mierina
}

\section{INTRODUCTION}

Much of the discussion of economic development and social dialogue in the Baltic states has concerned the convergence paradigm. Catching up with the 'old' European Union (EU) member states, in particular the Scandinavian countries, has been a natural target (Staehr 2015). The social dialogue, social protection and social models have been viewed from that perspective, for example, in arguing that at the lower level of income, extensive social protection and generous welfare states are not only unaffordable but may also hamper countries' future growth performance, in a kind of 'growth first' paradigm (Trumm 2006). The categorisation of the Baltic states in welfare state typologies or among the varieties of capitalism has been as either a liberal model, although not following exactly any of the four European systems (cf. Masso and Paas 2007) or a 'flexible market economy' (Kuokštis 2011). On that basis, we should ask whether social convergence - catching up in terms of a broader set of indicators characterising a broader development - is related to income convergence, and what else in addition to income convergence is needed to achieve social convergence. Another explanation for the close association between economic and social convergence is that, under the dominance of right-wing parties in coalition governments, trade unions have linked many of their arguments with economic development instead of the social sphere (Peterson 2018). Estonian employers, however, have sometimes expressed a different view, namely, that social convergence has been put before economic convergence (Tamsar 2018). Hence the need for further study of the topic. Such widely differing views on convergence are also to be expected given that wage convergence and harmonisation of working conditions are seen as the core goals of economic union ( $\mathrm{Naz}$ et al. 2017). The relevant question is whether the relatively undeveloped and embryonic forms of social dialogue in the Baltic states - referred to in terms of, for example, 'illusory corporatism' (Ost 2000), 'fragile shell' (Pollert 2000) or a 'talk-show' (Meardi 2012) - could endanger social convergence even under favourable economic conditions.

As convergence is by definition a long-run phenomenon, in this chapter we rely on information and statistics from the past ten, and in many cases even 20, years. The available statistical material from various sources is complemented by interviews with representatives of the social partners in order to reveal their views on economic and social 
convergence, the relevant topics in this regard, their evaluation of performance hitherto, the possible best practices and remaining challenges. As the benchmark in the statistical analyses we have used the EU15 (EU member states prior to the 2004 enlargement round) instead of the EU28. The interviews were made with Peep Peterson, chairman of the Estonian Trade Union Confederation (Peterson 2018) and Toomas Tamsar, president of the Estonian Employers' Confederation (Tamsar 2018).

The chapter is structured as follows. In section 2 we review the economic convergence performance of the Baltic states. While the literature on convergence is almost exclusively on income, in the following sub-sections we look at how income dynamics are related to the dynamics of other social indicators. Section 2 studies long-run developments in terms of economic convergence, while Section 3 looks at the various social convergence indicators and how these may have been influenced by social dialogue. The three case studies look deeper into the particular mechanisms by means of which economic and social convergence interact. The first case study looks at the emergence of new forms of working as a development that may affect convergence in the future and the role of the social partners in this regard. The second case study, on the contribution of the diaspora and return migrants to social dialogue, is particularly important for small, open economies subject to major outward migration (causing a brain drain), although migration may also have positive effects on convergence through such channels as return migration. The third case study, on the effects of foreign ownership, is important because of the intended benefits of foreign direct investment (FDI) in terms of capital, technology transfer, internationalisation and increased competition, but the positive effects on broader social indicators are likely to be problematic, for example, in terms of increased inequalities or negative effects on social dialogue.

\section{ECONOMIC CONVERGENCE: AN EXEMPLARY CATCH-UP PROCESS}

Among the central and eastern European countries the convergence performance of the Baltic states in terms of gross domestic product (GDP) per capita has been highlighted (Leitner and Römisch 2015), based on radical economic reforms and a quick transition to a market economy, a stable macroeconomic environment and business-friendly regulations. They are portrayed as open economies with few constraints on international trade or capital mobility. In the period 1995-2011 the Baltic states had one of the highest growth rates in the EU, averaging 4.0 per cent in Estonia, 4.1 per cent in Latvia and 4.3 per cent in Lithuania compared with the EU15's 1.6 per cent (authors' calculations based on data from the annual macro-economic database of the European Commission's Directorate General for Economic and Financial Affairs, AMECO). This pushed their GDP per capita up to more than 70 per cent of the EU27 average (Table 2.1), so that all the Baltic states are now classified as high-income countries by the World Bank (World Bank 2018). Similar to some least developed EU countries, such as Bulgaria and Slovenia, in Latvia and Lithuania, and less so in Estonia, growth in per capita GDP is related to a sizeable reduction in the workforce: during 1995-2011 the average population reduction rate was 1 per cent in Latvia and Lithuania owing to both a negative natural increase and outward migration, especially after joining the EU in 2005 . While decreasing population numbers 
Table 2.1 Economic convergence indicators for the Baltic states, 1995-2015

\begin{tabular}{llrrrrr}
\hline Indicator & Country & 1995 & 2005 & 2015 & $\begin{array}{r}\text { Difference } \\
1995-2015\end{array}$ & $\begin{array}{c}\text { Difference } \\
\text { 2005-15 }\end{array}$ \\
\hline GDP per capita & Estonia & 34.6 & 59.7 & 75.0 & 40.4 & 15.2 \\
at PPS, EU & Latvia & 30.6 & 50.2 & 64.4 & 33.8 & 14.2 \\
$27=100$ & Lithuania & 32.9 & 52.7 & 74.7 & 41.9 & 22.1 \\
& EU15 & 116.6 & 113.2 & 108.5 & -8.2 & -4.8 \\
GDP per capita, & Estonia & 13.2 & 35.4 & 53.4 & 40.2 & 18.0 \\
EUR & Latvia & 11.0 & 26.2 & 42.7 & 31.7 & 16.5 \\
& Lithuania & 9.3 & 27.0 & 44.5 & 35.2 & 17.5 \\
Gross disposable & EU15 & 124.4 & 119.7 & 115.8 & -8.5 & -3.9 \\
income & Latonia & 9.1 & 55.1 & 60.8 & 51.7 & 5.6 \\
per capita, & Lithuania & 14.4 & 33.6 & 62.9 & 48.5 & 29.2 \\
corporations, & EU15 & 125.9 & 22.5 & 51.5 & 44.5 & 28.9 \\
EU 27=100 & & 119.0 & 114.6 & -11.0 & -4.5 \\
Gross disposable & Estonia & 13.7 & 29.5 & 48.3 & 34.6 & 18.7 \\
income & Latvia & 10.0 & 26.0 & 40.6 & 30.5 & 14.6 \\
per capita, & Lithuania & 9.1 & 28.5 & 44.4 & 35.3 & 15.9 \\
households, & EU15 & 124.6 & 120.0 & 116.5 & -8.1 & -3.5 \\
EU 27=100 & & & & & & \\
\hline
\end{tabular}

Note: PPS denotes purchasing power standard and is used to account for the differences in price levels across countries. We refer to the EU15 as that could be a natural target for the Baltic states in the convergence process. For Estonian gross disposable income per capita we have reported the value for 1996 instead of 1995 as the latter was very low compared with both 1994 and 1996 (1.4), thus the value of 1996 is more representative of the long-run trends.

Source: Authors' calculations based on the AMECO database.

have contributed to an increasing per capita GDP and negatively to GDP growth (IMF 2015), the emigration of especially younger and more educated workers may worsen the Baltic states' future growth prospects (Hazans and Philips 2009). As regards the particular sources of growth, as revealed by growth accounting, for the period 1995-2016 there was a modest negative contribution from labour (from -1 per cent of total growth in Estonia to -5 per cent in Lithuania), while 57 per cent in Estonia and 77 per cent in Lithuania came from capital, and growth in total factor productivity accounted for 43 per cent in Estonia and 29 per cent in Lithuania (Levenko et al. 2017). The period after the crisis, 2010-16, was characterised by a negligible (even negative) contribution of total factor productivity to growth that coincides with the overall weak growth performance.

The average growth rate has to be viewed in conjunction with volatility across business cycles having been high, even considering the smallness of the countries (OECD 2012; IMF 2015). However, it has been shown that at least the Estonian economy is well diversified, including its exports, despite its small size (OECD 2017a), and the high GDP variation has been due instead to country-specific shocks (for example, the Russian crisis in 1999 and the major decline during the Great Recession) rather than specialisation in high-volatility sectors (OECD 2012). High macroeconomic volatility may also hamper 
long-run growth performance (Kose et al. 2005). The beginning of the transition was characterised by an output decline that was deeper than in other central and eastern European countries (during 1989-94 it was -37 per cent in Estonia and -46 per cent in Latvia, authors' calculations based on the World Development Indicators database), termed in the transition literature the 'J-curve' (Iwasaki and Kumo 2018) This was followed by strong growth in 1995-98 (averaging 6.5 per cent in Estonia and 4.0 per cent in Latvia). The decline in 1998-99 owing to the Russian economic crisis was modest in absolute terms, for example, -1 per cent in Lithuania, and followed by strong growth, especially after joining the EU in 2004 (the average for 2000-2008 was 8.5 per cent for Estonia, 8.8 per cent for Latvia and 7.5 per cent for Lithuania). There was probably a causal linkage between EU membership and subsequent growth: Estonia was found to be the country with probably the highest positive impact from joining the EU (Campos et al. 2014). Burduli (2017) similarly found that the rate of convergence (the distance from steady-state GDP that is closed in a year) between the new EU10 countries and the EU15 countries increased during the post-accession period (from 5.6 per cent to 9.0 per cent). However, the imbalances during the latter - growth fuelled by strong credit inflow that was later reversed and pro-cyclical fiscal policy - were also reasons why during the Great Recession the GDP decline in the Baltic states in 2008-09 was the highest in the EU, at -14 per cent in Estonia and -18 per cent in Latvia and Lithuania. Such high volatility of GDP (for example, related to open economies and limited automatic fiscal stabilisers) may also endanger long-run economic and social convergence, for example, because it contributes to outward labour migration (see, for example, Ramey and Ramey 1995). To avoid the business cycles negatively affecting convergence performance studies have stressed the importance of monitoring the domestic macroeconomic balances of the euro-zone countries (European Central Bank 2012, also relevant to the Baltic states) and the regulation of the banking and financial sector (Adams-Kane et al. 2016).

The Great Recession was followed in $2010-11$ by strong recovery, while several EU member states suffered a second wave of recession due to the sovereign debt crises and public sector austerity. Owing to the relatively slow growth thereafter, the convergence discussion talks of a 'middle-income trap', ${ }^{1}$ for example, in relation to the exhaustion of previous sources of economic growth such as a cheap labour and latecomer advantages (Pruchnik and Zowczak 2017 argue that this is not the case, while Staehr 2015 leaves the possibility open). However, an exact estimate of whether this is the case is hampered by the vagueness of the concept of 'middle-income trap'. In the case of the Baltics it may also be partly related to difficult economic conditions in some of their main export partners, such as Finland and Russia in the case of Estonia (OECD 2017a). Finally, the regional aspect has been important: Smetkowski and Wojcik (2012), studying the relative GDP growth paths of countries grouped in four macro-regions based on their economic behaviour (Slovenia, the Visegrad countries, the Baltic states, and Bulgaria and Romania), found a strong influence of regional polarisation, or convergence clubs, also in the case of the Baltic countries. They claim that such a polycentric structure can weaken economic convergence as the range of influence of each centre is low.

It is worth noting the differences between various GDP or gross domestic income (GDI) components in contrast to the 'balanced growth path' pattern; that is, wage developments closely follow developments in per capita income. In all three Baltic states, compared with households, companies have demonstrated much stronger convergence 
dynamics: both started at around 10 per cent of the EU27 level in 1995, but, while household incomes reached 40-48 per cent of GDP, corporations achieved 52-63 per cent of GDP. Furthermore, disposable corporate income grew at an annual average of 9 per cent and that of households at 4.8-5.8 per cent annually.

Among the different labour market and social indicators, that whose dynamics follows income convergence most closely is wages. ${ }^{2}$ Overall, the wage convergence pattern for the Baltic countries is largely similar to that of income convergence, with a rapid increase in wages after joining the EU, especially during the years preceding the Great Recession, decelerating during the recession and a fast recovery shortly afterwards, in 2010-12 (see Table 2.2). The wage share of GDP has been traditionally lower in the Baltic states than in other central and eastern European countries, compared with the old EU member states (see, for example, Galgóczi, and Mermet 2003 for earlier evidence), and we do not observe here a clear-cut pattern of convergence over time. The significantly higher wage share in Estonia as compared with Latvia and Lithuania reflects higher wages there. In the social dialogue the Estonian unions pay attention to wage share, although no target country has been selected in which the wage share is higher than the current Estonian

Table 2.2 Convergence of wage indicators, Baltic states and EU15, 1995-2015

\begin{tabular}{|c|c|c|c|c|c|c|}
\hline \multirow[t]{2}{*}{$\begin{array}{l}\text { Indicator and source } \\
\text { database }\end{array}$} & \multirow[t]{2}{*}{ Country } & \multicolumn{3}{|c|}{ Values of indicators } & \multicolumn{2}{|c|}{$\begin{array}{l}\text { Difference over the } \\
\text { period, percentage wage } \\
\text { growth }\end{array}$} \\
\hline & & 1995 & 2005 & 2015 & 1995-2015 & $2005-15$ \\
\hline \multirow{4}{*}{$\begin{array}{l}\text { Gross monthly wage, } \\
\text { national currency, } \\
\text { UNECE, EUR }\end{array}$} & Estonia & 153.8 & 516.4 & 1064.7 & 592.5 & 106.2 \\
\hline & Latvia & & 350.2 & 817.8 & & 133.5 \\
\hline & Lithuania & 140.9 & 369.9 & 713.3 & 406.2 & 92.8 \\
\hline & EU15 & 1890.2 & 2658.5 & 3272.1 & 73.1 & 23.1 \\
\hline Wages relative to & Estonia & 8.1 & 19.4 & 32.5 & 24.4 & 13.1 \\
\hline \multirow{3}{*}{ EU15 } & Latvia & & 13.2 & 25.0 & & 11.8 \\
\hline & Lithuania & 7.5 & 13.9 & 21.8 & 14.3 & 7.9 \\
\hline & EU15 & 100.0 & 100.0 & 100.0 & 0.0 & 0.0 \\
\hline \multirow{4}{*}{$\begin{array}{l}\text { Wage share, total } \\
\text { economy, AMECO }\end{array}$} & Estonia & 56.0 & 47.5 & 52.9 & -3.1 & 5.4 \\
\hline & Latvia & 48.3 & 45.6 & 50.9 & 2.5 & 5.3 \\
\hline & Lithuania & 46.0 & 49.1 & 47.6 & 1.6 & -1.5 \\
\hline & EU15 & 57.1 & 55.5 & 56.2 & -0.9 & 0.7 \\
\hline \multirow{4}{*}{$\begin{array}{l}\text { Wage share, } \\
\text { manufacturing, } \\
\text { AMECO }\end{array}$} & Estonia & 65.6 & 62.7 & 68.1 & 2.5 & 5.4 \\
\hline & Latvia & 51.0 & 53.9 & 54.8 & 3.8 & 0.9 \\
\hline & Lithuania & 53.8 & 49.9 & 44.6 & -9.3 & -5.3 \\
\hline & EU15 & 66.0 & 63.8 & 61.2 & -4.8 & -2.6 \\
\hline \multirow{4}{*}{$\begin{array}{l}\text { Wage inequality, } \\
\text { D9/D1 Structure of } \\
\text { Earnings Survey }\end{array}$} & Estonia & & 4.35 & 3.9 & & -0.45 \\
\hline & Latvia & & 5.96 & 4.23 & & -1.73 \\
\hline & Lithuania & & 4.64 & 3.92 & & -0.72 \\
\hline & EU15 & & 3.17 & 3.13 & & -0.04 \\
\hline
\end{tabular}

Note: The data from the SES are for 2006 and 2015 instead of 2005 and 2015.

Source: AMECO, United Nations Economic Commission for Europe (UNECE) Statistical Database, Eurostat Structure of Earnings Survey (SES). 
level (Peterson 2018). Estonian employers have been worried about declining profitability owing to rapid wage growth; although it pushes companies to increase efficiency, it also poses a risk for economic growth (Tamsar 2018). We should be careful in overstressing the effects of social dialogue on inequality indicators across the Baltic states, although there could be some limited effect, given the employers' positive attitude to minimumwage increases in Estonia (Tamsar 2018) and active lobbying against that in Latvia.

However, the gap between Estonia and the other Baltic states has not changed substantially. While average wages in Latvia and Lithuania amounted to 64 per cent and 71 per cent, respectively, of average wages in Estonia in 2004, in 2016 these numbers were 75 per cent and 68 per cent, respectively. The difference in the pace of wage convergence between the Baltic states following the Great Recession can have several explanations. One reason for this decrease is that wage growth exceeded productivity growth to varying degrees before the recession. Other arguments that might explain this include a different degree of success in the introduction of the euro after the recession or diverse adjustment patterns at the firm or sectoral levels (Masso and Krillo 2011). The results could also be influenced by the share of unreported wages and 'envelope wages' that has been an important phenomenon in the Baltic states labour markets (Kriz et al. 2008). Actual average wages might be underestimated as a result. The issue of underreporting wage and income is more noticeable for Latvia, which also explains the higher share of the shadow economy there: in 2016, it was 20.3 per cent in Latvia, 16.5 per cent in Lithuania and 15.5 per cent in Estonia (Putninš and Sauka 2017), while envelope wages account for the largest share of the shadow economy in Estonia (53.6 per cent) and less so for Latvia and Lithuania (42.4 and 40.2 per cent) as a result of the lower degree of, and incentives for, business income underreporting in Estonia owing to its corporate income tax setting (Masso et al. 2013). The extent of wage underreporting remained largely unchanged for the Baltics during the 2000s (Putninš and Sauka 2011), while during the period 2009-16 underreporting remained stable in Estonia and Lithuania (between 15 and 20 per cent), but decreased significantly in Latvia, from 34 per cent in 2009 to 18.1 per cent in 2016 (Putninš and Sauka 2017).

As regards patterns of wage growth across sectors, Table 2.3 presents the cumulative growth rates of wages at the sectoral level for the post-recession period after 2011, using net wages. We can see that in many sectors, such as wholesale and retail, the Baltic countries experienced a common trend in net wage growth. However, in a number of country-specific sectors, such as mining and quarrying in Latvia and Lithuania, accommodation in Lithuania, and education, information and communications in Estonia, there is a distinct pattern of rapid net wage growth not copied by the other Baltic states. Finally, a different pattern of wage growth in Estonia for 2011-17 (44.1 per cent average net wage for Lithuania and 48.2 per cent for Latvia, but 57.1 per cent for Estonia) allows us to further confirm the general diverging wage trend between the Baltic states.

As for wage inequalities, during 1989-2011 wage inequality in Estonia was unstable: it increased rapidly at the beginning of the transition (especially in the lowest part of the wage distribution, the D5/D1 ratio), decreased during 1998-2006 (especially in the lower part of the wage distribution as characterised by the D5/D1 ratio), and increased thereafter (Masso et al. 2014). The rapid convergence rate of the Baltic states with the EU average has thus been reflected in general wage increases rather than in changes in the wage distribution. Table 2.4 illustrates such developments by looking at another 
Table 2.3 Average percentage net wage change for selected industries, Baltic states, 2012-16

\begin{tabular}{|c|c|c|c|c|c|c|c|c|c|c|c|c|}
\hline & \multicolumn{3}{|c|}{$\begin{array}{l}\text { Mining and } \\
\text { quarrying }\end{array}$} & \multicolumn{3}{|c|}{$\begin{array}{c}\text { Wholesale and retail } \\
\text { trade }\end{array}$} & \multicolumn{3}{|c|}{$\begin{array}{l}\text { Information and } \\
\text { communication }\end{array}$} & \multicolumn{3}{|c|}{ Education } \\
\hline & $\mathrm{EE}$ & $\mathrm{LV}$ & LT & $\mathrm{EE}$ & LV & LT & $\mathrm{EE}$ & $\mathrm{LV}$ & LT & $\mathrm{EE}$ & LV & LT \\
\hline 2012 & -1.5 & 1.2 & 10.5 & 7.9 & 5.2 & 4.4 & 7.1 & 4.7 & 4.2 & 2.4 & -0.2 & 1.9 \\
\hline 2013 & -0.2 & 4.9 & 15.4 & 12.4 & 11.9 & 10.5 & 12.6 & 11.1 & 8.4 & 9.8 & 4.2 & 6.0 \\
\hline 2014 & 9.3 & 13.8 & 20.7 & 19.3 & 23.5 & 17.8 & 15.3 & 17.9 & 12.9 & 17.9 & 11.2 & 7.5 \\
\hline 2015 & 9.2 & 19.7 & 20.2 & 27.2 & 34.5 & 23.2 & 24.0 & 25.8 & 25.1 & 29.5 & 18.5 & 10.2 \\
\hline 2016 & 14.0 & 28.1 & 28.6 & 32.0 & 41.2 & 34.1 & 39.9 & 30.3 & 34.9 & 38.8 & 20.4 & 17.5 \\
\hline $\begin{array}{l}\text { Average } \\
\text { annual } \\
\text { growth }\end{array}$ & 2.7 & 5.1 & 5.2 & 5.7 & 7.2 & 6.1 & 7.0 & 5.4 & 6.2 & 6.8 & 3.8 & 3.3 \\
\hline
\end{tabular}

Note: $\quad \mathrm{EE}=$ Estonia, $\mathrm{LV}=$ Latvia, $\mathrm{LT}=$ Lithuania.

Source: Authors' calculations based on Statistics Estonia, Statistics Latvia and Statistics Lithuania databases.

Table 2.4 Wage bill distribution by year, Estonia, 1989-2013 (\%)

\begin{tabular}{lcccccccccc}
\hline & Q10 & Q20 & Q30 & Q40 & Q50 & Q60 & Q70 & Q80 & Q90 & Gini index \\
\hline 1989 & 2.6 & 3.8 & 4.8 & 5.6 & 6.6 & 7.5 & 8.5 & 10.0 & 13.2 & 0.414 \\
1993 & 2.3 & 3.9 & 5.0 & 6.0 & 7.2 & 8.6 & 9.6 & 11.7 & 14.5 & 0.379 \\
1995 & 2.0 & 3.7 & 5.0 & 6.0 & 7.5 & 8.6 & 10.4 & 12.3 & 15.7 & 0.375 \\
1997 & 2.6 & 4.2 & 5.3 & 6.6 & 7.6 & 8.9 & 10.4 & 12.2 & 15.1 & 0.344 \\
1999 & 2.9 & 4.3 & 5.4 & 6.5 & 7.6 & 9.0 & 10.6 & 12.2 & 15.3 & 0.333 \\
2001 & 3.4 & 4.8 & 5.8 & 6.7 & 7.9 & 9.2 & 10.4 & 12.1 & 14.7 & 0.308 \\
2003 & 3.5 & 5.1 & 6.0 & 7.0 & 8.1 & 9.1 & 10.5 & 12.1 & 14.6 & 0.294 \\
2007 & 3.0 & 4.7 & 5.8 & 6.8 & 7.9 & 9.1 & 10.5 & 12.2 & 14.9 & 0.340 \\
2009 & 3.1 & 4.7 & 5.5 & 6.6 & 7.8 & 9.0 & 10.4 & 12.1 & 15.1 & 0.348 \\
2011 & 2.6 & 4.4 & 5.4 & 6.5 & 7.6 & 8.7 & 10.1 & 11.9 & 15.2 & 0.373 \\
2013 & 2.7 & 4.4 & 5.5 & 6.6 & 7.7 & 8.9 & 10.4 & 12.2 & 15.2 & 0.361 \\
\hline
\end{tabular}

Source: Authors' calculations based on Estonian Labour Force Survey data.

indicator: the share of total wage bill going to different percentiles of the wage distribution. Since 2007 there has been a slight increase in wage inequality in terms of the Gini coefficient. However, when looking at the results of the Eurostat Structure of Earnings Survey (SES), across all indicators from 2006 to 2010 and 2014 (the data for 2002 did not include the Baltics), we can observe decreasing wage inequality across all indicators (for example, in Estonia the D9/D1 ratio went down from 4.35 to 3.9), but they remain a lot higher than in the EU15 (3.13 in 2014). Although that has been possible even in conditions of limited social dialogue and collective bargaining, we may be naturally cautious about how long this may continue. 
One of the most important dimensions of labour inequalities in the Baltics is gender. The situation is especially striking in Estonia owing to its very high gender pay gap, the highest in the EU and second highest among the Organisation for Economic Co-operation and Development (OECD) countries (see Anspal 2015 for a thorough overview), estimated at around 30 per cent in a range of data-sets and periods. Using various regression-based decomposition techniques the explained part of the gap has been found to represent only one-third of the total gap, the most important components being industry and occupation of the relevant employee. Compared with the very high unadjusted gender pay gap, in terms of the overall gender pay gap (Eurostat's synthetic indicator also takes into account employment and hours) Estonia has been somewhere in the middle, on 38 per cent, with Latvia and Lithuania recording some of the lowest gaps, at 23 per cent and 19 per cent, respectively, in 2014 (see also Table 2.5). That is because both the number of hours worked and employment rates have contributed little to the overall gender gap owing to the low incidence of part-time employment, both among females and males, and the modest gender employment gap in all countries. Women's lower wages are striking because of the higher female educational attainment; for the 30-34 age category, Latvia and Lithuania have some of the highest gender gaps - favouring women - in tertiary education attainment, at 27 and 20 percentage points, respectively. The other side of the

Table 2.5 Gender gap indicators, Baltic States, 2005-14

\begin{tabular}{|c|c|c|c|c|c|c|c|}
\hline \multirow[t]{2}{*}{$\begin{array}{l}\text { Country } \\
\text { and year }\end{array}$} & \multirow{2}{*}{$\begin{array}{l}\text { Unadjusted } \\
\text { gender pay } \\
\text { gap }\end{array}$} & \multirow{2}{*}{$\begin{array}{c}\text { Gender } \\
\text { employment } \\
\text { gap, } \\
\text { percentage } \\
\text { points }\end{array}$} & \multirow{2}{*}{$\begin{array}{l}\text { Gender } \\
\text { monthly } \\
\text { hours } \\
\text { gap }\end{array}$} & \multirow{2}{*}{$\begin{array}{c}\text { Overall } \\
\text { gender } \\
\text { pay gap } \\
(\%)\end{array}$} & \multicolumn{3}{|c|}{$\begin{array}{l}\text { Contribution of various components } \\
\text { to gender pay gap }\end{array}$} \\
\hline & & & & & $\begin{array}{l}\text { Gender } \\
\text { pay gap }\end{array}$ & $\begin{array}{c}\text { Gender } \\
\text { hours gap }\end{array}$ & $\begin{array}{l}\text { Gender } \\
\text { employment } \\
\text { rate gap }\end{array}$ \\
\hline $\begin{array}{l}1997 \\
\text { Estonia } \\
\text { Latvia } \\
\text { Lithuania } \\
\text { EU28 }\end{array}$ & 23.0 & 11.0 & 13.2 & 43.1 & 58.2 & 14.4 & 27.4 \\
\hline $\begin{array}{l}2005 \\
\text { Estonia } \\
\text { Latvia } \\
\text { Lithuania } \\
\text { EU28 }\end{array}$ & $\begin{array}{l}25.0 \\
16.0 \\
15.0\end{array}$ & $\begin{array}{r}4.9 \\
9.8 \\
8.4 \\
15.9\end{array}$ & $\begin{array}{r}10.4 \\
13.2 \\
9.2 \\
29.6\end{array}$ & $\begin{array}{l}34.4 \\
32.7 \\
28.9\end{array}$ & $\begin{array}{l}68.3 \\
44.0 \\
47.6\end{array}$ & $\begin{array}{l}15.6 \\
20.3 \\
17.6\end{array}$ & $\begin{array}{l}16.1 \\
35.7 \\
34.8\end{array}$ \\
\hline $\begin{array}{l}2014 \\
\text { Estonia } \\
\text { Latvia } \\
\text { Lithuania } \\
\text { EU28 }\end{array}$ & $\begin{array}{l}28.2 \\
17.4 \\
13.1 \\
17.2\end{array}$ & $\begin{array}{r}7.7 \\
4.6 \\
2.5 \\
11.5\end{array}$ & $\begin{array}{r}8.4 \\
6.0 \\
5.6 \\
26.4\end{array}$ & $\begin{array}{l}38.4 \\
22.8 \\
19.2 \\
39.6\end{array}$ & $\begin{array}{l}68.2 \\
73.7 \\
65.9 \\
37.4\end{array}$ & $\begin{array}{l}19.8 \\
23.9 \\
11.4 \\
32.1\end{array}$ & $\begin{array}{r}12.0 \\
2.4 \\
22.6 \\
30.5\end{array}$ \\
\hline
\end{tabular}

Note: Overall gender pay gap variables for 2014 were taken from Eurostat data and for other years calculated independently using the same decomposition formulas.

Source: Eurostat, national statistical offices. 
story is that the highest gender gap in life expectancy is also to be found in the Baltics (9.5 years in Estonia and 10.9 years in Lithuania). ${ }^{3}$ Generally, in all three Baltic countries we do not see much convergence towards a reduction of the gender pay gap; its reduction during the Great Recession (Masso and Krillo 2011) seems to be a temporary phenomenon because male-dominated sectors were harder hit by the crisis, a situation that was reversed during the recovery.

It is surprising that Estonia has so much larger a gender pay gap in comparison to Latvia and Lithuania despite their very strong similarities in other indicators. Part of the story could be the differences in occupation segregation; that is, while the share of females among managers is much lower in Estonia (38 per cent, Vahter and Masso 2018), Latvia has a very high percentage of women in managerial positions, particularly in middle management (a few years ago it was the highest in Europe, LSM 2017), so there is little apparent prejudice against women in the labour market. Another possible reason is values, where some striking differences can be noticed: the values of the Hofstede masculinity indicator are 30 for Estonia, 9 for Latvia and 19 for Lithuania - Latvia is one of the most feminine countries (Hofstede Insights 2018).

One peculiarity of working-time distribution in the Baltic states has been its high concentration at 40 hours, corresponding to full-time employment. Looking at the distribution of working time according to European Working Conditions Survey data, all Baltic states have a very high concentration round 40 hours: 64.3 in Estonia, 61.3 in Latvia and 62.4 in Lithuania, compared with the EU28, where it is just 31.2 (Anxo 2018). Looking at the kernel density plots of hours, at least in Estonia such very strong concentration of hours around the 40 mark has even been deepening over the years (authors' calculations from Estonian Labour Force Survey data). The numbers are fairly similar for women (65.4 for Estonia compared with 26.6 for the EU28). This reflects the very limited extent of part-time work even among women; in 2016 part-time employment constituted just 9.9 per cent of total employment in Estonia (compared with 19.5 per cent in the EU28), and even less in Latvia and Lithuania (4.9 and 5.9 per cent, respectively), while among women it constituted just 13.3 per cent of total employment (31.9 per cent among women in the EU28, Eurostat). The Great Recession saw some changes in this regard, with most of the adjustment occurring in relation to employment (numerical flexibility) and wages (even basic wages); average hours were reduced significantly, by 2 per cent in Estonia and Latvia, compared with 0.5 per cent in the rest of the EU (Masso and Krillo 2011). Despite that, in the long run there has not been significant convergence in working-time indicators.

The first question that arises concerns whether convergence in working time should occur owing to income or wage convergence. Table 2.6 shows some modest convergence in terms of hours, such as decreasing average hours for full-time employees. The limited, or even lack of, convergence in working-time indicators is surprising given that there has been strong growth in wages; the standard argument explaining a low incidence of parttime employment is that low wages make it difficult to afford a decent living standard while working part-time (Tang and Cousins 2005).

The low part-time employment may be explained by the Soviet past, which probably requires more time to change, but also by the low share of the service sector at the beginning of the transition, although that has been increasing. The Estonian social partners stress that full-time working is a cultural phenomenon: even pay increases have not 
Table 2.6 Working time convergence, Baltic States, 1995-2015

\begin{tabular}{|c|c|c|c|c|c|}
\hline & Country & 1995 & 2005 & 2015 & $\begin{array}{l}\text { Difference } \\
1995-2015\end{array}$ \\
\hline Average & Estonia & 42.7 & 41.3 & 40.8 & -1.9 \\
\hline working hours & Latvia & 44.1 & 42.7 & 40.6 & -3.5 \\
\hline of full-time & Lithuania & 42.9 & 39.4 & 39.6 & -3.3 \\
\hline employed & $\begin{array}{c}\text { European Union } \\
\text { (15 countries })\end{array}$ & 42 & 41.8 & 41.4 & -0.6 \\
\hline Share of & Estonia & 8.0 & 5.2 & 6.6 & -1.4 \\
\hline part-time & Latvia & 12.1 & 6.2 & 4.9 & -7.2 \\
\hline employees, & Lithuania & 7.5 & 5.3 & 5.9 & -1.6 \\
\hline males & $\begin{array}{c}\text { European Union } \\
\text { (15 countries })\end{array}$ & 5.1 & 7.6 & 11.0 & 5.9 \\
\hline Share of & Estonia & 12.5 & 10.8 & 15.2 & 2.7 \\
\hline part-time & Latvia & 12.5 & 10.4 & 10.8 & -1.7 \\
\hline employees, & Lithuania & 9.7 & 9.2 & 10.5 & 0.8 \\
\hline females & $\begin{array}{c}\text { European Union } \\
\text { (15 countries })\end{array}$ & 31.3 & 36.0 & 38.4 & 7.1 \\
\hline
\end{tabular}

Note: For 1995, we have sometimes used for Estonia data from 1997, Latvia and Lithuania data from 1998.

Source: Authors' calculations from Eurostat database.

motivated people to decrease working hours (Peterson 2018), and full-time employment is a norm for both employers and employees (Tamsar 2018). Another important reason is the tax treatment of part-time work, namely, the relatively high minimum social tax contribution (Peterson 2018). In 2018 the minimum level of social tax is calculated from a gross wage of $€ 470$, in other words, the minimum social tax is $€ 155.10$ per month (the social tax rate is 33 per cent in Estonia). This fixed minimum rate means that it is financially unprofitable for the employer to hire part-time workers in low-wage jobs. By some estimates that would make part-time working disadvantageous for around 60 per cent of potential part-time jobs (Peterson 2018). Trade union representatives have discussed changing the situation with the government, but without results so far.

To summarise, limited part-time employment in the Baltic states compared with much of the rest of the EU means that while trade unions in many other EU countries are resisting part-time employment, in Estonia it is viewed positively, especially with regard to groups with lower labour market participation, although no targets have been set (Peterson 2018). Thus, more extensive use of part-time working would help to reduce some of the existing labour shortages, and social dialogue may have some role here in the future. However, the number of workers not working owing to limited availability of part-time jobs is not too big, and more use of such employment may also reduce overall labour input via lower hours or impact on current full-time employees (Tamsar 2018).

The employment rates (Table 2.7) and labour force participation rates have been stable in the Baltic states during the period analysed, reflecting also women's comparatively high labour market participation as an effect of the Soviet heritage and path-dependency. The rates have also increased substantially over recent years. Probably there are limited 
Table 2.7 Long-term trends in employment, unemployment and labour market participation in the Baltic states, 1995-2015

\begin{tabular}{llrrrrr}
\hline Indicator & Country & 1995 & 2005 & 2015 & $\begin{array}{r}\text { Difference } \\
\text { 1995-2015 }\end{array}$ & $\begin{array}{c}\text { Difference } \\
\text { 2005-15 }\end{array}$ \\
\hline Employment & Estonia & 64.9 & 64.8 & 71.9 & 7.0 & 7.1 \\
rate, 15-64 & Latvia & 59.8 & 62.1 & 68.1 & 8.3 & 6.0 \\
& Lithuania & 62.4 & 62.9 & 67.2 & 4.8 & 4.3 \\
& EU15 & 60.6 & 65.3 & 66.2 & 5.6 & 0.9 \\
Labour force & Estonia & 72.4 & 70.7 & 76.7 & 4.3 & 6.0 \\
participation & Latvia & 69.8 & 69.1 & 75.7 & 5.9 & 6.6 \\
rate, 15-64 & Lithuania & 72.2 & 68.7 & 74.1 & 1.9 & 5.4 \\
& EU15 & 67.9 & 71.1 & 73.5 & 5.6 & 2.4 \\
Unemployment & Estonia & & 8.0 & 6.2 & & -1.8 \\
rate, 15-64 & Latvia & & 10.0 & 9.9 & & -0.1 \\
& Lithuania & 13.2 & 8.3 & 9.1 & -4.1 & 0.8 \\
Youth & EU15 & 9.6 & 7.4 & 10.2 & 0.5 & 2.8 \\
unemployment & Estonia & 18.7 & 15.1 & 13.1 & -5.6 & -2.0 \\
rate, 15-24 & Latvia & 27.0 & 15.1 & 16.3 & -10.7 & 1.2 \\
& Lithuania & 25.2 & 15.8 & 16.3 & -8.9 & 0.5 \\
& EU15 & 21.2 & 16.6 & 20.3 & -0.9 & 3.7 \\
\hline
\end{tabular}

Note: For 1995, for Estonia we have sometimes used data from 1997, Latvia and Lithuania data from 1998.

Source: Authors' calculations based on the Eurostat database.

possibilities for further increases in employment rates to support economic convergence and tackle labour shortages. ${ }^{4}$ As for the social partners' arguments about tackling labour shortages, the unions have pointed to higher employment rates in other countries, such as Norway, the importance of attracting Estonians working abroad to return home and the danger of viewing immigration as the solution (although they are not completely against that, Peterson 2018), as employers do (Tamsar 2018). However, the problem with the current relatively strict migration regulations, with limited quotas, ${ }^{5}$ is that companies get around them with temporary workers from countries with more liberal immigration policies, such as Poland and Lithuania, who are low paid and do not pay taxes in Estonia (Tamsar 2018). The labour shortages have also negatively affected FDI to Estonia (Tamsar 2018).

Immigration rates in the Baltic states have been low. In the EU and OECD countries the rate of immigration reached, on average, 0.7 per cent of total inhabitants in 2015 but, for example, in Latvia it was just 0.3 per cent (OECD 2017b). The attitude towards immigration among the majority of the population of the Baltic states is negative. According to 2017 Eurobarometer data (Eurobarometer 2017), 44 per cent of the inhabitants of Latvia have a negative attitude towards immigration from the EU, and 81 per cent a negative attitude towards immigration from outside the EU. In Estonia and Lithuania attitudes towards intra-EU immigrants are mostly positive and do not differ from the average in the EU28, but there is still a lot of prejudice against migrants from outside the EU: 76 per cent of people in Estonia and 62 per cent in Lithuania have negative attitudes towards 
immigration from outside the EU (Eurobarometer 2017). People overwhelmingly do not recognise the contribution of immigrants to the country's economic growth: 86 per cent, 78 per cent and 61 per cent of respondents in Latvia, Estonia and Lithuania, respectively, disagree that immigrants contribute a lot to their country (Eurobarometer 2017). At the policy level, the approaches to immigration in the Baltic states differ. While Estonia has tried to attract foreign workers, changing regulations and working on its attractiveness as a destination country (Johanson 2017), in Latvia realisation of the importance of immigration for economic growth has been slow, particularly against the backdrop of negative population attitudes. Prejudice and xenophobia in combination with restrictive immigration and citizenship policies, as well as insufficient understanding of antidiscrimination practices and intercultural communication at workplaces further inhibit the potential to attract foreign workers. Currently, a significant proportion of immigrants (apart from return migrants) in Latvia come from the countries of the Commonwealth of Independent States (CIS), such as Ukraine and Russia. Their motivation is fuelled by the widespread use of the Russian language in various sectors of the economy, in combination with more competitive wages than in the migrants' home countries. Nevertheless, they too often prefer wealthier EU countries as their destination. The Estonian experience as regards migration is the best; since 2015 international net migration has been positive and in 2017 it became positive also among Estonian citizens (Statistics Estonia database).

The unemployment rates, though very volatile over time, reflecting both the large swings in business cycles and flexible labour markets, have also decreased substantially over time. The lower unemployment rates during the transition period reflected more successful reforms and rapid reallocation of labour to other activities, for example, via occupational mobility (Campos and Dabušinskas 2009). These numbers have also greatly affected wage convergence: while high unemployment rates combined with weaker unions in the earlier period restrained wage increases, after EU accession in 2004 the fall in unemployment rates contributed to upward wage pressures. Similar to other EU countries, youth unemployment has been a problem, especially during the crisis period, but youth unemployment as a proportion of overall unemployment has been broadly similar in the Baltic states in comparison with the EU.

Another issue that is particularly important in relation to convergence is the skills of the labour force. The Baltic states have a high, and increasing, level of education. In Estonia, higher education attainment increased in the 15-64 age group between 1995 and 2015 from 25.3 per cent to 33.3 per cent (compared with a rise from 15.5 to 28 per cent in the EU15, Eurostat). It is important to note in connection with the high level of tertiary education that especially in Estonia students, particularly postgraduate students, are also working (19 per cent in the case of those living with parents, the second highest number after Poland, Hauschildt et al. 2015). Although spending on education has been below the EU15 average, ${ }^{6}$ the quality of education is high and Estonia in particular has performed very well in international rankings such as PISA, even attaining the best results in Europe in PISA 2015 (OECD 2018). However, there are still challenges ahead concerning how to achieve economic convergence while making use of workers' education and training, as existing business models are focused on low labour costs. Education and skills are key to avoiding the middle-income trap (Staehr 2015). The education sector in the Baltic states and especially in Estonia is one of the few with collective agreements, and in the unions' opinion it sets a positive example (Peterson 2018). 
The importance of social dialogue in this sector has the potential to affect issues such as quality. As one positive example of this, in recent years teachers' wages in Estonia have risen substantially thanks to collective agreements, not so much as a result of social dialogue but of government support. This should also boost the sustainability and quality of education by attracting young people to become teachers, given the high average age of teachers in Estonia (Masso et al. 2016). As regards digital skills, in Estonia the share of individuals with average or above average digital skills was above the EU average (60 and 57 per cent, respectively), but lower in Latvia and Lithuania (48 and 55 per cent, Eurostat). The employers' view is that especially the quality and perceived image of vocational education remain a challenge, but so do lifelong learning and retraining (Tamsar 2018). However, according to the data of the Estonian Labour Force Survey (ELFS), the share of the labour force in education or training during the past four weeks of the time of the survey has been rising in Estonia, from a comparatively low level in 2005 (6 per cent versus 11.1 per cent in the EU15) to a much higher level (15.7 per cent versus 12.5 per cent in the EU15); it remains a challenge in Latvia and Lithuania (in 2016, 7.3 and 6 per cent, respectively). To conclude, skills and education should be one of the major issues for future social dialogue in the Baltic states.

\section{SOCIAL CONVERGENCE: WELL BELOW PAR IN A CONTEXT OF WEAK INDUSTRIAL RELATIONS}

Social convergence can be defined in terms of a safe and active working environment, social benefits such as unemployment compensation and the presence of consistent dialogue between employees and employers, including collective bargaining involving unions (Marginson and Meardi 2007). Owing to the low level of attention paid to this in the process of integrating new EU member states, more study is required. One summary indicator of this is income inequality. While the Baltic states have been similar in terms of overall economic development, long-run growth performance and business cycles, income inequality dynamics have differed strikingly in terms of the Gini coefficient (Masso et al. 2014), showing sometimes divergence rather than convergence. The Estonian dynamics perhaps resembles most the logic of the Kuznets curve, with an initial increase and thereafter decreases of inequality in the course of economic development, while in the cases of Latvia and Lithuania the increase in inequality was delayed (Table 2.8). Among the different explanatory factors for the different dynamics the diverging patterns of skill premiums are particularly important. Cho and Diaz (2018) showed that between 1995 and 1998 the skill premium increased by almost 16 per cent in Latvia, while it declined in Estonia by 30 per cent and in Lithuania by 13 per cent. The differing results could be because the factors decreasing the skill premium - an increase in relative skill supply due to increased higher education attainment - dominate in Estonia and Lithuania, while the forces increasing the skill premium - growth of capital investment in combination with capital/skill complementarity - dominate in Latvia. As regards poverty indicators, we can observe decreasing poverty rates especially in Latvia and Lithuania, but poverty remains at much higher levels than in the EU15.

The observable patterns of inequalities in the Baltic states are driven largely by inequalities in market incomes, as demonstrated by the relatively more modest role 
Table 2.8 Inequality convergence indicators, Baltic states, 1995-2015

\begin{tabular}{llccccc}
\hline Indicator & Country & 1995 & 2005 & 2015 & $\begin{array}{c}\text { Difference } \\
1995-2015\end{array}$ & $\begin{array}{c}\text { Difference } \\
\text { 2005-15 }\end{array}$ \\
\hline Gini index, & Estonia & 39.5 & 33.5 & 34.6 & -4.9 & 1.1 \\
World Bank & Latvia & 31.0 & 39.0 & 35.1 & 4.1 & -3.9 \\
estimate & Lithuania & 33.6 & 35.3 & 37.7 & 4.1 & 2.4 \\
& EU15 & 31.0 & 31.4 & 32.0 & 1.0 & 0.6 \\
Income share & Estonia & 31.4 & 26.2 & 26.2 & -5.2 & 0.0 \\
held by the & Latvia & 25.1 & 30.0 & 26.6 & 1.5 & -3.4 \\
highest 10\% & Lithuania & 28.0 & 27.2 & 28.9 & 0.9 & 1.7 \\
& EU15 & 25.1 & 24.9 & 25.0 & -0.1 & 0.0 \\
Income share & Estonia & 2.5 & 2.7 & 2.4 & -0.1 & -0.3 \\
held by the & Latvia & 3.2 & 2.0 & 2.3 & -0.9 & 0.3 \\
lowest 10\% & Lithuania & 3.4 & 2.2 & 2.1 & -1.3 & -0.1 \\
& EU15 & 3.2 & 3.1 & 2.9 & -0.3 & -0.2 \\
People at risk & Estonia & - & 25.9 & 24.2 & & -1.7 \\
of poverty and & Latvia & - & 46.3 & 30.9 & & -15.4 \\
social exclusion & Lithuania & - & 41 & 29.3 & & -11.7 \\
& EU15 & - & 21.02 & 22.28 & & 1.26 \\
Youth & Estonia & 18.7 & 15.1 & 13.1 & -5.6 & -2.0 \\
unemployment & Latvia & 27.0 & 15.1 & 16.3 & -10.7 & 1.2 \\
rate, 15-24 & Lithuania & 25.2 & 15.8 & 16.3 & -8.9 & 0.5 \\
& EU15 & 21.2 & 16.6 & 20.3 & -0.9 & 3.7 \\
\hline
\end{tabular}

Source: World Development Indicators, Eurostat.

of social transfers in poverty reduction. In general, the Baltic states' social model is characterised by relatively limited welfare states (also the result of limited industrial relations) or most resembles the liberal model, although some elements and policy learning indicate the influence of the Nordic and conservative models (Aidukaite 2006). At least in terms of the total share of social protection expenditures as a share of GDP, there has been no convergence and the shares are at a stable low level compared with those of the EU15 (Table 2.9). ${ }^{7}$ The lower expenditure can be seen in various indicators, such as lower health spending and lower replacement rates for pensions. The old-age dependency ratio, though below the EU average, is set to increase, which in turn increases the possibility of a growth slowdown (Staehr 2015). We may argue that in certain dimensions the Estonian health-care system has been efficient and the structural changes in Latvia adopted during the crisis were necessary for that purpose. However, with regard to many health indicators, such as self-reported unmet needs for medical care, the Baltic states lag behind the old EU member states. Improvements can be seen over past ten years, however, especially in Latvia and Lithuania. The better performance of Estonia in terms of social convergence indicators is due to a combination of factors, and social dialogue is one little piece of the larger picture. Especially in the case of Latvia it is very much down to a skewed tax system that benefits the wealthy at the expense of low-paid workers, as well as weak social support, which the government tries to justify mainly with ideological considerations (Masso et al. 2014). If civil society was more politically active and trade 
Table 2.9 Some key indicators concerning labour market and social protection institutions, Baltic states, 1995-2015

\begin{tabular}{|c|c|c|c|c|c|c|}
\hline Indicator & Country & 1995 & 2005 & 2015 & $\begin{array}{l}\text { Difference } \\
1995-2015\end{array}$ & $\begin{array}{c}\text { Difference } \\
2005-15\end{array}$ \\
\hline \multirow{4}{*}{$\begin{array}{l}\text { Minimum wage as } \\
\text { percentage of } \\
\text { mean wage } \\
\text { (Kaitz index) }\end{array}$} & Estonia & 18.9 & 33.3 & 36.6 & 17.7 & 3.3 \\
\hline & Latvia & 32.0 & 32.8 & 44.0 & 12.0 & 11.2 \\
\hline & Lithuania & 28.1 & 39.2 & 50.5 & 22.4 & 11.3 \\
\hline & EU15 & & 50.5 & 41.9 & 17.7 & \\
\hline \multirow{4}{*}{$\begin{array}{l}\text { Social protection } \\
\text { expenditure as } \\
\text { a percentage of } \\
\text { GDP }\end{array}$} & Estonia & & 12.5 & 16.4 & & 3.9 \\
\hline & Latvia & 14.6 & 12.2 & 14.9 & 0.3 & 2.7 \\
\hline & Lithuania & 13.1 & 13.2 & 15.5 & 2.4 & 2.3 \\
\hline & EU15 & 26.5 & 26.6 & 29.5 & 3.0 & 2.9 \\
\hline \multirow{5}{*}{$\begin{array}{l}\text { Impact of social } \\
\text { transfers } \\
\text { (excluding } \\
\text { pensions) } \\
\text { on poverty } \\
\text { reduction }\end{array}$} & Estonia & & 25.6 & 22.3 & & -3.3 \\
\hline & Latvia & & 16.1 & 17.6 & & 1.5 \\
\hline & Lithuania & & 24.8 & 22.4 & & -2.4 \\
\hline & EU15 & & 41.0 & 39.9 & & -1.0 \\
\hline & & & & & & \\
\hline \multirow{4}{*}{$\begin{array}{l}\text { Health expenditure } \\
\text { as a share of } \\
\text { GDP, Eurostat }\end{array}$} & Estonia & & 3.9 & 4.6 & & 0.7 \\
\hline & Latvia & 2.6 & 3.3 & 3.6 & 1.0 & 0.3 \\
\hline & Lithuania & 3.9 & 3.9 & 4.5 & 0.6 & 0.6 \\
\hline & EU15 & 7.0 & 7.3 & 8.3 & 1.3 & 1.0 \\
\hline \multirow{4}{*}{$\begin{array}{l}\text { Average } \\
\text { replacement rates } \\
\text { of pensions }(\%), \\
\text { Eurostat }\end{array}$} & Estonia & & 47.0 & 43.0 & & -4.0 \\
\hline & Latvia & & 61.0 & 42.0 & & -19.0 \\
\hline & Lithuania & & 47.0 & 46.0 & & -1.0 \\
\hline & EU15 & & 52.0 & 57.0 & & 5.0 \\
\hline \multirow{4}{*}{$\begin{array}{l}\text { Self-reported } \\
\text { unmet need for } \\
\text { medical care, } \\
\text { Eurostat }\end{array}$} & Estonia & & 6.4 & 12.7 & & 6.3 \\
\hline & Latvia & & 18.5 & 8.4 & & -10.1 \\
\hline & Lithuania & & 6.9 & 2.9 & & -4.0 \\
\hline & EU15 & & 3.8 & 3.4 & & -0.4 \\
\hline
\end{tabular}

Source: Eurostat, national statistical agencies.

union organisation was higher, things might have been different, but that is only one factor among several.

The social partners can exert influence by becoming involved in the different bodies of the social protection system, such as the councils of the Estonian Unemployment Insurance Fund and the Estonian Health Insurance Fund. Thus the social partners in Estonia have had most impact on unemployment insurance. However, their influence on policy-making has been limited. For example, changes have not always been targeted on the ultimate goals of the fund, as demonstrated by the breakdown of the tripartite social dialogue on the Unemployment Insurance Fund and the Health Insurance Fund owing to disagreements on the size of contributions to the former and the use of reserves (Osila 2012). Another negative example is the recent reform of labour legislation in Estonia whereby the initially agreed 'security' part of the flexicurity package (in particular the payment of unemployment insurance benefits on termination of the employment 
contract by mutual agreement) was not adopted (Masso et al. 2015). According to the unions this may have led to the job losses during the Great Recession, which contributed to later labour shortages (Peterson 2018), thus extending the protection of the unemployed, but also helping them to find new jobs that correspond better to their skills should enter into future policy discussions. The trade unions also believe (Peterson 2018) that the incomes of retired people and the unemployed are too low in Estonia; for example, the government has not set a target for pension replacement rates. Employers take the view that the government should tackle population ageing by promoting saving (Tamsar 2018).

To summarise, while it is hard to outline clear cases in which the involvement of social partners has led to better outcomes, they can negotiate both the setting of unemployment insurance rates and the general aims of the Estonian Unemployment Insurance Fund, and they have been assertive. In addition to the negative experiences of trade union involvement, there are positive examples, such as the unemployment insurance rate, which was changed by agreement of the social partners in accordance with the economic situation, and the debates in the Unemployment Insurance Fund on options for reducing structural unemployment.

In particular, the distribution of labour income matters for inequality, and wage inequality has been high in the Baltic states. The institutional context of wage setting is particularly important, namely, the low union density and lack of collective bargaining. Furthermore, over the past 20 years there has been a downward trend in unionisation. For example, between 1995 and 2015 union density fell from 32 per cent to 6.5 per cent in Estonia, from 25 per cent to 13.1 per cent in Latvia and from 15 per cent to 9 per cent in Lithuania (Visser 2015). ${ }^{8}$ There has been some debate about whether joining the EU in 2004 may have had positive effects on unionisation but, if anything, the previous decline has continued. One other potential effect could be cross-country cooperation with unions in the neighbouring Scandinavian countries and the European-level trade union organisations. Such developments, as well as the documented limited effect of unions, for example on wage formation (Eamets and Kallaste 2004), may explain the persistent disparities and inequalities in the labour market. Where there have been positive trade union effects - for example, moderating adjustments during the crisis (Masso and Krillo 2011) or reducing the gender pay gap (Masso et al. 2018) - their effect at the aggregate level has been hampered by their small size.

Inequalities are further increased by the limited extent of sectoral collective agreements and bargaining mainly at company level (Glassner 2013), although we can find some positive developments, such as in the education sector. However, we might well ask whether social dialogue was the main factor or was there a political will to make the change happen. In our interview with Peep Peterson, the head of the Estonian Trade Union Confederation explained that collective agreements are signed mainly in sectors in which wages are above average or above the median; therefore collective agreements have not had a positive effect on wage compression. Peterson said that in his experience the lower the wage, the lower the inclination of workers to start collective agreement negotiations. Moreover, the low paid are not in a position to pay union membership fees and would rather change job than join the union (Peterson 2018). In addition to wages, the shortage of sectoral agreements is an issue as regards various exceptions to working-time regulations: the unions have proposed that, instead of legislative exceptions, working time should be regulated by collective agreements, but employers are reluctant to do this, for example, owing to fears of possible 
strikes (Peterson 2018). In the employers' opinion there should be fewer collective agreements as employees now have a stronger bargaining position (Tamsar 2018).

A review of trade union influence on industrial relations in Latvia and Hungary (Korkut et al. 2017) has found the same underlying challenges, but different approaches to solving them. The unions face modern challenges caused by structural changes, such as alternative communication channels and skilled-labour shortages in some sectors of the economy. Outward labour migration could have offered unions an opportunity to strengthen their bargaining position, as it generated labour shortages and, in consequence, upward pressure on wages (Krings 2009). While some unions are adapting, even without government help, and attracting new members and young specialists, others lack the flexibility to change and instead focus on existing members. Both are effective only to a certain extent (Korkut et al. 2017). Facing outward labour migration and a rise in unemployment to 20 per cent during the crisis, in addition to the challenges of democratisation in a new state, Latvia decided to address some of these issues with neoliberal government policies. It now has only one trade union confederation, focused mainly on the science and education, transport and health-care sectors (Korkut, et al. 2017).

Owing to limited collective bargaining, the national minimum wage has an especially important role in protecting low-wage workers and influencing wage dynamics and convergence (see Figure 2.1 for dynamics over the past 20 years). Minimum-wage setting is done with the agreement of the social partners and confirmed by the government, so this is clearly an area in which social dialogue may influence convergence. While at the aggregate level minimum-wage developments have often followed rather than led the aggregate wage developments, social convergence may occur through a reduction in the number of working poor, as shown by Ferraro et al. (2018) in relation to minimum-wage increases



Source: National statistical offices, Eurostat, authors' calculations.

Figure 2.1 Ratio between the minimum wage and the average wage (Kaitz index), Baltic states, 1995-2016 
in Estonia during 2011-14, which reduced wage inequalities via positive spillover effects in the lower part of the wage distribution. Toomas Tamsar, the head of the Estonian Employers' Confederation, explained that the social partners have agreed to increase minimum wages rapidly in Estonia because all parties recognise that poverty polarises society and so it is a 'matter of social responsibility' (Tamsar 2018). The president of the Estonian Trade Union confederation, Toomas Peterson, confirmed that the recent increases in the minimum wage are probably the best example of the effect of social dialogue on convergence (Peterson 2018).

In minimum-wage negotiations, for the trade unions both wage compression (reduction in wage inequality) and a general wage increase or convergence are important (Peterson 2018). For the purposes of convergence, a 6 per cent wage increase has been set as a target, and for the minimum wage the trade unions want it to be at least 40 per cent of average wage with the prospect of moving up to 50 per cent later. An important issue taken into consideration in the minimum-wage negotiations and affecting convergence is migration - in the trade unions' opinion the recent wage increases, and the contribution of the minimum-wage increase, are among the reasons behind Estonia's positive net international labour migration since 2015 (partly also owing to high return migration), for instance in the transport sector. While employers have warned against high wage growth undermining productivity, the trade unions believe that they have obtained wage increases owing to labour shortages caused by positive net migration. Another argument is that the minimum-wage differences between countries should reflect the differences in labour productivity, based on which, comparing Estonia and Germany, the Estonian minimum wage should be $€ 100$ higher (Peterson 2018). As for the other Baltic states, in Latvia it is unlikely that the minimum-wage increase is leading to significant return migration (based on surveys it is still a small amount of money for those working abroad), but it should reduce outward migration as the inability to survive on the current income is one of the main reasons pushing people to emigrate (Mierina 2015).

To conclude, we note that the discussion of the role of social dialogue in convergence has focused on incomes. One reason highlighted by the unions (Peterson 2018) is that some of the other relevant dimensions, such as work safety, the influence of working conditions on health (for example, number of healthy life years) and participation in lifelong learning (where information is not available for all relevant groups), are harder to compare internationally owing to measurement and statistical issues. The discussion of wage issues would benefit from the availability of additional indicators such as median wages, but there are other topics that should be in focus, such as average working age, although this should be viewed in the context of the retirement age.

\section{CASE STUDY 1: THE 'SHARING ECONOMY' AS PART OF CONVERGENCE - HOW CAN INDUSTRIAL RELATIONS HELP?}

\subsection{Introduction}

Developments in the Estonian labour market in recent years indicate increasing change. The emergence of new forms of work poses challenges to policy-makers. The main chal- 
lenge is the social security system. New forms of work often do not 'fit into' the traditional social security system, meaning that people in non-traditional forms of employment are not covered by social protection, as recently noted by the European Economic and Social Committee's own-initiative opinion (EESC 2017). They may or may not be considered to be employed. This means that new forms of working may have an impact on social convergence in terms of employment, wages, income, and so on. Also, the emergence of new working forms is likely to change industrial relations because such workers are less likely to unionise and remain isolated. Since it is highly likely that this trend will continue in coming years, it is important to develop solutions to the inherent risks, including the social partners.

In the case study we focus on a segment of the so-called 'sharing economy' that has experienced major regulatory changes in recent years, which its advocates call 'transportation by agreement'. We also review the development of the 'sharing economy' in Estonia over the past decade. In the case study we have combined data from several sources. First, we looked at previous studies mapping labour market developments as regards new forms of work in the Estonian labour market in recent years. Second, qualitative data were gathered via interviews carried out as part of this study. We interviewed Peep Peterson, the head of the Estonian Trade Union Confederation, Toomas Tamsar, director of the Estonian Employers' Confederation, and Hannes Lents, head of the union for the 'sharing economy', the Sharing Economy Alliance. This approach proved to be very successful because it turned out that not all developments and challenges could be reflected in quantitative data.

\section{2 'Sharing' Services Sector in Estonia}

In Estonia, the 'sharing' services sector has been characterised by rapid growth and expansion. The first 'sharing economy' companies in Estonia were established in the late 2000s, but 'sharing economy' practices have become popular since 2013, when companies such as Taxify (established in 2013), Crowdestate (2014), Uber (2015) and Toitla (2015) entered the market. In Estonia the estimated turnover of the 'sharing economy' platforms was $€ 0.87$ million in 2012 and $€ 6.5$ million in 2015 (these include only the turnover of the commission fees of the 'sharing' platforms, not the total turnover created in the sector ${ }^{10}$ ). This means that in only three years total turnover in the sector increased more than 7.5 times. During 2011-15 turnover growth was considerably higher in the 'sharing' sector than in the economy as a whole ( 80 per cent for 'sharing economy' enterprises compared with only 5 per cent for the total economy - sectoral average) (Eljas-Taal et al. 2016).

Also, the number of companies operating in the 'sharing economy' increased from eight in 2012 to 48 by the end of 2016. In 2016, 15 'sharing economy' companies were operating in the finance sector, seven in the transport sector, 13 in accommodation and travel management, 11 in individual and business services, and two offered educational services (Eljas-Taal et al. 2016).

In their study, Eljas-Taal et al. (2016) stressed that, for sustainable long-term economic development, support is needed for the development of the 'sharing economy', as is a relaxation of business regulations across the board. The authors of the study recommend introducing a new business form for 'freelancers', which could attract private persons to offer their services outside their professional activities. This is because it is highly likely 
that a commitment to one employer or one online platform will disappear in the future and people will need more flexibility when supplying their labour.

\subsection{Regulating 'Transportation by Agreement': The Estonian Experience}

On 14 June 2017 the Estonian Parliament passed what came to be known as the 'Uber Act', more precisely, amendments to the Public Transport Act. It took more than a year to develop the draft law and several times the process was restarted from scratch. With these amendments, the services provided under the rubric of 'transportation by agreement'11 (in Estonian 'kokkuleppevedu') between natural and legal persons were regulated and the rules governing taxi transportation were eased. The Act entered into force on 1 November 2017. The debates on the draft law were heated. Estonia is one of the few countries that has legitimised so-called 'Uber activities' in its territory. The new law relaxed the rules on providing transportation services and minimum standards were implemented for providers of 'transportation by agreement' services and related electronic systems.

The need for such regulation arose mostly because of market needs. The letter of explanation of the aforementioned draft law stipulates: 'Innovative services, what can be defined as the "sharing economy" 12 exist in a legal vacuum at the moment because current legislation did not foresee the emergence of such services or the increase in the use of such services that has occurred' ('Letter of explanation on the amendment of the Public Transport Act' 2016, p. 1). It also stresses the importance of demand: 'It is important that sharing services, [the category in which] "transportation by agreement" is placed, are driven by strong demand from customers and it is almost impossible to restrain them by regulations' ('Letter of explanation on the amendment of the Public Transport Act' 2016, p. 1).

\subsection{Challenges to the Social Security System}

Some groups of workers are insufficiently covered by social guarantees, including people providing 'transportation by agreement' services. If they do this only as a side-job, the problem is less urgent because their main job provides them social security coverage (unemployment insurance and health insurance). However, if they provide such services as their only work-related activity, they are covered by the social security system only in certain circumstances. ${ }^{13}$ That is, the Estonian social security system is still meant mainly for traditional employment. However, with the emergence of new working forms, additional possibilities are needed to better protect people. Currently it is not an urgent problem because most people provide such services as a side job, according to Hannes Lents, the representative of the Sharing Economy Alliance. However, since it is estimated that such service provision is on an upward trend, the problem is likely to affect an increasing number of people in the future.

Health insurance is one of the most important social security measures (in addition to unemployment insurance, but there are as yet no measures to provide safeguards against unemployment to people working other than under a labour contract in Estonia). There are three ways to get health insurance for people in non-traditional employment in Estonia. These can be used by people who provide 'transportation by agreement' services 
and do not have health insurance coverage via other channels. First, a person can register as unemployed. ${ }^{14}$ Second, they can enter into a voluntary insurance contract with the Estonian Health Insurance Fund ${ }^{15}$ (Eesti Haigekassa 2018). Third, they can use a business account. This possibility was created with the Simplified Business Income Taxation Act that entered into force on 1 January 2018. A natural person may open a business account for sums received on which business income tax is paid. The rate of business income tax is (1) 20 per cent of the amount received in the business account if it does not exceed $€ 25000$ in a calendar year, or (2) 40 per cent if the amount exceeds $€ 25000$ in a calendar year. For comparison, the personal income tax rate is 20 per cent and the social security tax rate 33 per cent in Estonia in 2018. If the monthly income of the business account is at least $€ 1300$, the person is covered by health insurance.

According to the head of the Sharing Economy Alliance, Hannes Lents, the union actively participated in social dialogue when the state created the new system. The main aim of developing the business account system was to decrease bureaucracy when declaring revenues obtained by supplying labour in forms other than a traditional labour contract. It is expected that the business account will help to increase tax revenues, because the system is very easy: a person opens the business account and tax is transferred automatically to the Tax and Customs Board.

In the interview Hannes Lents also drew attention to the bottlenecks of the business account system, the most important of which is that such accounts can be used only for transactions between two natural persons. Thus it is not possible to use a business account for services provided by a natural person to a legal entity, which may arise in relation to 'transportation by agreement' services. Some service providers are thus still excluded from health insurance. Another problem is that banks are not eager to provide business account services as they are uncertain about how large demand will be.

\subsection{Safety at Work and Occupational Health Issues}

Another important area is work safety and occupational health. In jobs where employees can work outside the office, for example, teleworking and remote working, it is difficult or impossible for employers to control working conditions. Nevertheless, the current law makes the employer responsible for employees' work safety and occupational health. These forms of working also pose challenges to Estonia's Labour Inspectorate. The question is, what are the Labour Inspectorate's rights with regard to controlling working conditions outside offices and other work places?

According to Hannes Lents, in the 'transportation by agreement' sector it is very difficult to control whether a person is following the working-time rules: someone can finish providing a service via one platform (for example, Uber) and start providing it via another platform (for example, Taxify). How should responsibility, obligations and risks be shared between the employer (or platform) and the employee (the so-called 'service provider' via a platform) in such circumstances?

\subsection{Conclusion}

New forms of work are emerging in the Estonian economy. The self-styled 'sharing economy', which has undergone rapid growth in Estonia during the past seven years, 
is a good example of this. Although, compared with traditional sectors, the 'sharing economy' turnover is negligible at the moment (in transportation just 0.1 per cent), it is expected to increase much faster in the future. Among the different spheres of the 'sharing economy', transportation is expected to grow the fastest - the estimated minimum growth of the sector during 2015-20 is 600 per cent, increasing the share of sharing economy in the total transport sector turnover to 0.7 per cent (Eljas-Taal et al. 2016). This was why we chose 'transportation by agreement' as a topic of the case study.

According to Hannes Lents, the government's aim is to promote the spirit of enterprise. This poses challenges to the social security system to protect people working in other forms than traditional labour contracts. Currently it is not a major problem because, in his opinion, most people providing 'transportation by agreement' services do so as a side job, so they get health and unemployment insurance from their main employer. However, it is likely that the need for new social security solutions will increase in the future when 'sharing economy' service providers decide to provide their labour mainly via the new forms of working.

Estonia currently is reacting on a case-by-case basis, developing regulations as the need arises. Although policy-makers tend to react by legislation, the President of the Estonian Trade Union Confederation stressed (Peterson 2018) that he sees an opportunity to increase the role of collective agreements. In his opinion it is not effective to make exceptions for single cases, but instead to provide more of a role for collective agreements (at sectoral level and, as the case may be, at company level) and trade unions.

\section{CASE STUDY 2: UTILISING THE KNOWLEDGE POTENTIAL OF THE DIASPORA AND RETURN MIGRANTS VIA SOCIAL DIALOGUE IN LATVIA}

\subsection{Introduction}

Latvia has one of the highest net emigration rates in Europe (Fries-Tersch et al. 2018). According to neoclassical growth models, migration should play a positive role in accelerating convergence (Barro and Sala-i-Martin 2004; McCann 2013). The negative effects of brain drain, reducing the productivity of stayers (Docquier et al. 2014) and lowering the stock of human capital (Haque and Kim 1995) should, in theory, be offset by real-wage convergence and expected positive productivity effects from return migration. Nevertheless, a recent analysis by International Monetary Fund (IMF) experts (Atoyan et al. 2016) demonstrates that mass migration from central and eastern European countries has instead hampered their economic growth and even slowed down income convergence. Among the reasons for this are the persistently low rates of return migration - for instance, as noted by Hazans (2016a), less than 40 per cent of Latvian emigrants return within ten years. The latest EU Commission report, 2017, on intra-EU mobility (Fries-Tersch et al. 2018) notes that return migration rates in EU13 countries have been decreasing in the past few years, and currently stand at the lowest level since 2009. Particularly troubling is the loss of skilled workers such as health-care professionals or information technology (IT) specialists (Hazans 2016a; Fries-Tersch et al. 2018). Nevertheless, there are a number of other mechanisms by which not just return migrants 
but also those choosing to remain abroad can shape a country's future. These include sharing their acquired knowledge and engaging as social partners in social dialogue with policy-makers, thus impacting policies and developments in various areas of life. ${ }^{16}$

The aim of this case study is to explore the effects of migration on social convergence via social dialogue, consultations and cooperation between the diaspora and the state. The analysis is based on policy planning and normative documents, reports from international organisations, national development planning documents, empirical studies and academic publications. Of particular importance in the case study are two focus group discussions with diaspora policy experts (including the Ministry of Foreign Affairs, the Ministry of Education and Science, the Society Integration Foundation, the Crosssectoral Coordination Centre, the Ministry of the Economy, the World Federation of Free Latvians (PBLA) and the European Latvian Union (ELA)) in November 2016 and June 2017.

\subsection{Potential Role and Impact of the Diaspora}

The myth that central and eastern European migrants working abroad are mostly low educated and in low-skilled jobs was disproved long ago. On the contrary, most intra-EU migrants have moderate to high levels of education (Fries-Tersch et al. 2018). In the case of Latvia, emigrants are not just substantially younger but also on average more educated than stayers (Atoyan et al. 2016). Many work as specialists in various fields, including finance, IT, manufacturing and public administration, or have acquired higher education abroad, so the diaspora possesses valuable human capital and can make a significant contribution to the development of the Latvian economy. They can contribute new ideas, skills and knowledge, promote investment in innovation, transfer of knowledge and the development of new products with high added value. ${ }^{17}$ They can also engage in social dialogue and help to develop more efficient policies related to their field of specialisation or social and economic issues in general, which is our main focus in this case study. Not surprisingly, many countries, especially those that are less prosperous and those with a large diaspora, pursue targeted diaspora policies aimed at strengthening links with members of the diaspora and exploiting their knowledge (Šupule et al. 2016). The importance of strengthening diaspora involvement in public dialogue in Latvia and achieving better circulation of knowledge and utilisation of their intellectual potential was emphasised in the Return Migration Support Action Plan 2013-2016 (Cabinet of Ministers of the Republic of Latvia 2013), and in the past few years, awareness of the diaspora's knowledge potential has been rising.

Surveys show that many of the diaspora are interested in cooperation and in helping the development of the country by sharing their knowledge in different ways (Hazans 2016b; Mierina et al. 2017a). A well as the two largest diaspora organisations, the ELA and the PBLA, lately various diaspora groups have been established that could be interested (or have already expressed interest) in influencing political and public processes in Latvia. As an example, the initiative 'the UK Latvian Business Network' has been running for over two years; its membership is over 750 and the leaders plan to expand and become a global initiative called the 'Global Latvian Business Group'. Returning professionals in Latvia and young entrepreneurs have joined together in the group 'With World Experience in Latvia' (APPL), which has attracted a lot of interest and membership. 
There are also some local groups such as the Norwegian-Latvian Chamber of Commerce and Industry. Selective networking was initiated in 2016 by the ELA, bringing together specialists in various fields such as doctors, lawyers and financiers. With the survey of the science diaspora in 2017 (Mierina et al. 2017a), there are calls for more active cooperation with Latvian scientists abroad, too. In answer to the demand, the ELA is currently working on the platform 'Team Latvia' in collaboration with business organisations and organisations in the United Kingdom and Norway, the Red Jackets, the APPL and other organisations, and continues to work on networking for various groups of professionals. Nevertheless, experts agree that there is currently no effective mechanism for mobilising and using the knowledge potential of the diaspora in the development of Latvia, and that, considering the size of the diaspora, much more needs to be done to facilitate its political involvement as social partners.

\subsection{Diaspora-specific Avenues of Impact}

It is not unusual for a country to establish different counselling mechanisms specifically targeted at the diaspora (Šūpule et al. 2016), and Latvia is no exception. In January 2011, the Ministry of Foreign Affairs signed a memorandum of cooperation with the PBLA, representing the interests of the diaspora in Latvia. In October 2013 a Working Group on Diaspora Politics headed by the Ministry of Foreign Affairs in cooperation with the Ministry of Culture was established ${ }^{18}$ which includes members of various institutions involved in diaspora and return migration policy, in addition to diaspora and return migrant organisations (Mierina et al. 2017b). Various non-institutionalised events are organised in order to promote the exchange of ideas and strengthen links with the diaspora. With the support of the state, the Global Economic and Innovation Forum of Latvians (PLEIF) is organised every four years. Every year, the Ministry of Culture organises the conference 'Latvians in the world - belonging to Latvia', which promotes dialogue between representatives of the Latvian government and the diaspora. The issues discussed concern almost exclusively diaspora matters or those related to return migration.

Recently, cooperation with the diaspora has become more intense, rich and diverse. Representatives of state institutions regularly participate in meetings of diaspora organisations, as well as in professional contact-building events. However, one challenge is the need for follow-up mechanisms to ensure that the ideas generated at the events become tangible and real initiatives (Aikins and White 2011, pp. 31-40).

With this in mind, following the PLEIF Forum in 2015, the Diaspora Business Advisory Council was established. Its members are entrepreneurs and investors with strong ties to North American, Australian and European Latvian communities and organisations. The organisation has so far presented its views both in the media in the form of public statements, and at formal meetings with state representatives (Ministry of Foreign Affairs, Latvian Investment and Development Agency) on aspects of development that they see as problematic for investors and entrepreneurs in Latvia, and that hinder growth and entrepreneurship, such as corruption, excessive bureaucracy, and legislative and technological issues. They have provided recommendations on the establishment of a database of diaspora professionals and improving conditions for return migration, recognition of foreign qualifications and the requirements of tender 
documents for state funding, improving the investment environment in the country, and so on. In 2016, representatives of the Council were invited by the Prime Minister to take part as observers in National Development Council meetings. Representative of the Council, Arnis Kākulis, comments:

In our opinion, it is important for the representatives of the diaspora to continue to participate in the meetings of the National Development Council in order to understand the country's development priorities and to be involved in discussing Latvia's national development issues. We see our contribution to the issues discussed in bringing in the experience and expertise of Latvian experts living outside the country and, accordingly, in raising awareness that the Latvian diaspora can make a significant contribution to the development of Latvia. (PBLA 2016)

Moreover, the value and potential of the Council lies in attracting the opinions of experts in the diaspora and helping to identify examples of good practice from other countries, including matters such as working conditions and employer-employee relations (often found to be problematic by Latvian returnees and diaspora), innovations and global competitiveness.

Currently, the activity and involvement of the Council in the development of state policy is minimal (Birka 2016), and its potential is not sufficiently used by public officials. Interviews with council members indicate that the further development of the Diaspora Business Advisory Council and the PLEIF requires more broad involvement of the new diaspora ${ }^{19}$ and closer cooperation with the Latvian Investment and Development Agency. In the ideal mode of cooperation, members of the council, depending on their sphere of activity, would be connected to existing state or legislative working groups on their sectors/spheres (Latvian Chamber of Commerce and Industry, Foreign Investors Council in Latvia or American Chamber of Commerce in Latvia), avoiding duplication of functions with, for example, the Latvian Chamber of Commerce and Industry or the Foreign Investors Council in Latvia. Currently, trade unions and employers' organisations have not specifically expressed interest in involving the members of the diaspora in discussions about labour and social issues.

\subsection{Potential Solutions and Ways Forward}

In order to achieve a more substantial policy impact in various areas, experts suggest that diaspora organisations take an active part in the Latvian Civic Alliance. This association serves as a non-governmental organisation (NGO) platform (125 members at August 2017): it follows the decision-making process in the government, participates in the Cabinet's meetings and ministries' working groups and weekly state secretary meetings, as well as in the meetings of Saeima committees in order to provide NGOs with stakeholder participation in drafting policy documents and legislation and changes to implementation.

As for legislative developments, experts recommend the involvement of NGOs and the diaspora (as well as the general public) in drafting policy documents discussing draft legislation at an early stage in their development. They also recommended that ministries publish an annual work plan for the development of normative and policy-making documents, planned working groups and public consultations in order to provide even more timely information. 
One of the major challenges in achieving a more active and meaningful diaspora engagement in social dialogue is organising and networking in groups or organisations. Increasing numbers of experts emphasise the need for an Internet platform or website to provide a technical opportunity for networking of professionals, but given the diaspora's diversity, it is unclear how to create an effective solution to this problem. Across the world, various diaspora networking platforms have been established. A successful hybrid approach is the Advance Australia network, which has a number of specific sectoral networks in the single network, such as the Financial Services Network and the Life Science and Green Technology Network. Experts believe that such a platform would also be necessary for connecting the Latvian diaspora and providing information about current political events and opportunities for engagement. 'One website is required, where I as a foreigner living in Latvia can receive additional information about what is happening and how can I get involved' (Discussant 1).

This newly created platform requires a very specific structure, goals, leadership and regular meetings. Platform members would try to influence the policy process by engaging in different stages of decision-making in specific sectors in Saeima commissions, public consultations and so on, working with existing structures (for example, Tech-hub) who are well aware of the local situation and current issues.

Many experts argue that creating a World Database of Diaspora Businesses and Professionals is vital for building sustainable and effective collaboration between professionals and business people. The database would make it easy to find and attract experts with the required qualifications and competences to help with knowledge on specific issues and regions, and invite them to various events. Currently, many organisations (the PBLA, Latvian Investment and Development Agency, Ministry of Foreign Affairs and the University of Latvia) have their own contact networks but, given their sensitive nature, it is unlikely that such information will be shared. However, cooperation is possible between organisations and institutions in supplementing the databases necessary for practical work between state institutions and diaspora organisations (Mierina et al. 2017b).

The state can provide financial support for existing and emerging diaspora networking initiatives (for example, the 'Global Latvian Business Group', ELA professional groups, 'With World Experience in Latvia'), thus strengthening these organisations as potential partners in social dialogue. Finally, smart, proactive and consistent communication with the diaspora is needed, with senior public officials calling for the diaspora to engage in networking and cooperation, thus contributing to the economic growth of the country. It is equally important not only to encourage participation in specific existing activities and programmes, but also to enable entrepreneurs and professionals themselves to apply and express their vision of where they would like to contribute.

\subsection{Conclusion}

Although 15 per cent of Latvians and Latvian nationals reside abroad, research shows that the potential of the diaspora is still not sufficiently understood by Latvian society and employers, as well as in decision-makers' circles (Hazans 2016b; SKDS 2016). This case study shows that there are still many opportunities to make use of the skills and knowledge acquired by migrants (both those living abroad and those who have returned 
to Latvia) by engaging them as partners in the social dialogue. Many diaspora professionals would like to keep in touch with Latvia and contribute directly or indirectly to its development. It is the task of the state in this situation to address the target group and provide opportunities to contribute. Many developments in this area are still ongoing, but awareness of the knowledge potential of the diaspora, regardless of their decision to return, is undoubtedly growing. Harnessing and utilising this knowledge in social dialogue is one way of offsetting the negative effects of emigration and driving convergence with the more prosperous European countries.

\section{CASE STUDY 3: WHAT ROLE FOR FDI IN INDUSTRIAL RELATIONS AND SOCIAL CONVERGENCE?}

\subsection{Introduction: Literature on Multinational Enterprises and Social Convergence}

Countries in central and eastern Europe face many additional challenges that slow convergence, particularly its social aspect, including rigid and weak legal systems (Meardi et al. 2010), weak and untrusted trade unions (Korkut et al. 2017), social and cultural features that promote inequality, adverse economic policy and the role of the region in the national economy (Meardi 2006). Another relevant aspect may be the strong FDI dependence (Marginson and Meardi 2007) that characterises the Baltic countries: inward FDI as a percentage of GDP in 2016 was 83 per cent in Estonia, 51 per cent in Latvia and 34 per cent in Lithuania (OECD data). Multinational companies play a major role in the social convergence process by fostering the implementation of the international directives and agreements in the countries in which they operate. However, they act with profit maximisation in mind and usually have little interest in complying with non-binding agreements as this incurs additional expenses (Balcioglu 2016). Lessmann (2013) argues that while FDI tends to increase the marginal product of labour, as well as output and consumption in the host region, making it richer and attractive for further investments, it also increases inequality, an effect that is more pronounced in low-income countries. ${ }^{20}$ Another argument against attributing social convergence to FDI is that one of the main motivations for multinational companies' investments is escaping certain legal constraints. They are unlikely to be willing to enforce their home-country legislation in the target country of investment. A permissive or less regulated legal framework in the target country concerning multinational companies also leads to more short-termism, which is not conducive to stable social dialogue (Marginson and Meardi 2007). In such circumstances it is much easier for multinationals expanding into central and eastern Europe to pursue congenial economic practices in their subsidiaries instead of those that are more socially favourable; that is, social convergence rates between countries are disproportionate. The existence of international framework agreements is not enough to foster progress, being 'a necessary but not a sufficient condition for the respect of workers' rights' (Lévesque et al. 2016, p. 13). Thus, the preponderance of multinationals is one example of why the spillover effect of economic unions in the form of economic convergence does not necessarily transfer to other areas of cooperation.

Another motivation for studying the Baltic states is that while, with respect to single-employer bargaining, collective bargaining coverage is typically higher among 
multinational companies than in the private sector on EU average, the Baltic states are an exception because the FDI is often concentrated in lower value-added sectors (Marginson and Meardi 2009).

This case study will thus look at the effects of FDI on social convergence from two angles: by providing a short literature review on the issue, and then a statistical analysis of the ELFS data for 2007-13. Some references are made also to interviews with the Estonian social partners and the respective Slovenian case study in this volume.

\subsection{Effect of FDI, Multinational Corporations and Trade Unions}

Multinational companies have been observed to both change and adapt to the markets they enter. The most common and direct way to calculate their influence is by analysing the effects of FDI. This cash inflow can be further categorised by purpose, area, country of origin, method of use and implementation. The main investments in central and eastern Europe, for instance, come from Germany and the United States. In general, as expected, long-term projects and greenfield investments are beneficial both to the employees and to social dialogue (Marginson and Meardi 2007). However, not all of those features affect convergence as one might expect. Marginson and Meardi (2007) in particular state that, for instance, in labour-intensive projects funded by multinationals workers are expected to play a larger role, and thus social convergence is likely to happen. In practice, workers at multinationals are largely unskilled and disorganised, and the unions generally do not intervene. These authors go on to talk about the disproportion FDI brings to the development of national economic sectors, leaning heavily towards the service sector and manufacturing. This tendency generally restricts union power in these sectors of the economy.

One reason for the slow progress in social dialogue is the general nature of European directives and the softer regulations initially imposed on the post-socialist countries as new EU members. Limited resources to encourage social dialogue, and that they are not legally binding, leads to a situation in which most multinationals develop their own human resource management practices for each national market, especially if 'hostile' cultural traditions are present (Meardi 2006). Therefore, instead of a government-tobusiness dialogue in these countries, a society-to-business dialogue is more prevalent. This does not mean that the situation cannot change in the future; on the contrary, both the social pressure acting from below and the overall standardisation of labour conditions across Europe, from above, could serve as a decisive factor as time goes by (Marginson and Meardi 2007).

Another example of this is the unions' role, which is generally weak in countries with stronger dependence on FDI. In Slovenia, by contrast, unions play a decisive role in social dialogue, although the country has a large FDI inflow (Meardi 2006). Estonia, however, has utilised much of its FDI for economic convergence with little or no union influence (Adam et al. 2008). Both are offset by the Poland example, where numerous labour code violations occurred in the 2000 s, even with an active union role (Meardi 2006). It also confirms that even when multinationals actively try to foster wage convergence, the resulting social dialogue model is different from that in the European directives. However, Slovenia, Estonia and Poland have experienced the same greenfield investment strategy: 'A greenfield investment appears to be important in two opposing situations: when the choice is dictated by union-avoidance strategies (Tóth 1999), or when 
the multinational intends to transfer its western model as faithfully as possible' (Meardi et al. 2005; Marginson and Meardi 2007, p. 101). While some countries, such as Slovenia, report a strong positive union role in negotiating with multinationals, others, such as Hungary or the Czech Republic, do not (Meardi 2006). Therefore, even if we assume that Slovenia is an outlier, there is currently no consensus between studies on the union role in convergence.

Current analysis of the effects of countries' economic development strategies on FDI and, in turn, FDI's impact on trade union power and economic growth indicates a larger role of FDI in central and eastern Europe in terms of the share of capital inflow in relation to the relatively small populations of these countries compared with western Europe (Meardi et al. 2010). The smallest trade union membership rates were observed in the more rapidly developing countries (Estonia, Lithuania, Latvia and Slovakia), which follows the general declining trend for union density. Higher FDI inflow leads to higher bargaining volatility, which incentivises the workers to bargain for themselves and decreases their reliance on the unions. The general conclusion here is that a large amount of FDI has a negative effect on union power. What is more, multinational companies usually meet migration with 'social dumping', offering lower wages and worse working conditions to migrants to minimise costs and capture a larger market share. Evidence of this can be found in central and eastern European countries such as Poland, Bulgaria and Hungary (Jefferys 2010).

The prevalence of permissive legal environments with regard to FDI seems to be almost universal in post-Soviet countries. Implemented to attract FDI, these relaxed conditions simultaneously create a substantial discrepancy in labour standards between central and eastern Europe and the rest of Europe. Even if the industry is not particularly labour intensive, other factors, such as tariffs and non-tariff barriers, the country's location, education and training, all contribute to creating a sufficiently different quality of labour force (Meardi 2006). There are several other factors, including low capital mobility, higher unemployment rate and distrust of national companies, and, conversely, greater autonomy for multinational subsidiaries in central and eastern Europe compared with western Europe, which creates a strong divergence effect in terms of social labour conditions. It is also important to stress that such discrepancies are much harder to solve from the affected countries, as they are competing for foreign investments, and even though unions mainly influence workers' wages positively compared with those of nonunion workers, other working conditions remain largely unaffected (Meardi 2006). Faro (2012) concluded that trade unions respond to the demands of multinationals by creating a structure that is economically different but socially and culturally identical to those of national companies.

\subsection{Empirical Analysis Using the Estonian Labour Force Survey Data}

Using the ELFS from 2007-13, we find several trends in the association of foreign direct ownership with union membership and wage gaps. For this reason, all observations are split into three categories: government and municipal ownership, local ownership and joint/foreign companies. For almost every employee, ownership of the employing organisation is stated in the data. Table 2.10 presents the number of respondents who are currently members of a union and whether a union is present in the company. The 
Table 2.10 Union membership and presence over the years, Baltic states, 2007-13 (\%)

\begin{tabular}{|c|c|c|c|c|c|c|c|c|}
\hline & & 2007 & 2008 & 2009 & 2010 & 2011 & 2012 & 2013 \\
\hline \multirow{2}{*}{$\begin{array}{l}\text { Government } \\
\text { and municipal } \\
\text { companies }\end{array}$} & Membership & 19.12 & 16.99 & 18.83 & 19.44 & 17.24 & 15.01 & 14.02 \\
\hline & Presence & 41.51 & 40.94 & 42.18 & 41.41 & 40.62 & 39.93 & 39.76 \\
\hline \multirow[t]{2}{*}{ Local companies } & Membership & 2.37 & 2.02 & 2.31 & 2.34 & 1.84 & 1.72 & 1.89 \\
\hline & Presence & 4.63 & 5.00 & 4.97 & 4.79 & 4.66 & 4.54 & 5.05 \\
\hline \multirow{2}{*}{$\begin{array}{l}\text { Joint and foreign } \\
\text { companies }\end{array}$} & Membership & 4.97 & 2.98 & 3.07 & 3.56 & 3.52 & 3.85 & 3.36 \\
\hline & Presence & 16.27 & 14.89 & 13.81 & 11.62 & 11.50 & 12.08 & 11.16 \\
\hline \multirow[t]{2}{*}{ Total } & Membership & 4.30 & 3.74 & 3.93 & 4.07 & 3.69 & 3.53 & 3.47 \\
\hline & Presence & 15.55 & 15.54 & 16.69 & 16.37 & 15.63 & 15.46 & 15.35 \\
\hline
\end{tabular}

Source: Authors' calculations based on the ELFS.

Table 2.11 Average working conditions by different types of company ownership by gender, Baltic states, 2007-13

\begin{tabular}{llcccc}
\hline Ownership type and gender & $\begin{array}{c}\text { Mean working } \\
\text { hours a week }\end{array}$ & $\begin{array}{c}\text { Worked } \\
\text { overtime }\end{array}$ & $\begin{array}{c}\text { Worked during } \\
\text { the weekend }\end{array}$ & $\begin{array}{c}\text { Used } \\
\text { teleworking }\end{array}$ \\
\hline $\begin{array}{c}\text { Government } \\
\text { and municipal }\end{array}$ & Female & 37.4 & $2.9 \%$ & $26.6 \%$ & $7.8 \%$ \\
companies & & 39.3 & $3.7 \%$ & $39.7 \%$ & $10.0 \%$ \\
Local companies & Female & 37.6 & $2.4 \%$ & $45.9 \%$ & $10.5 \%$ \\
Joint and foreign & Male & 40.4 & $3.5 \%$ & $37.4 \%$ & $11.7 \%$ \\
companies & Female & 38.8 & $2.5 \%$ & $35.6 \%$ & $4.1 \%$ \\
Total & Male & 41.3 & $4.6 \%$ & $34.5 \%$ & $6.7 \%$ \\
& Female & 37.7 & $2.6 \%$ & $37.2 \%$ & $8.4 \%$ \\
\hline & Male & 40.4 & $3.7 \%$ & $37.2 \%$ & $10.4 \%$ \\
\hline
\end{tabular}

Source: Authors' calculations based on the ELFS, 2007-13.

results show a decline in union membership over the years in all categories of ownership, while the percentage of employees in companies where there is the possibility of joining a union remains largely stable, with the exception of foreign and joint venture companies, where union ownership is decreasing over time.

Next, we analyse the percentage of employees who have received training in the month of the survey. This indicator exhibits an increase in 2008-13 (in 2007 the question was not included in the ELFS) from 7.2 per cent to 9.2 per cent. The general increase might be attributed to structural changes in economies following the Great Recession, with higher numbers for local and government companies representing higher demand and resources for training (in that group we saw an increase from 12.1 per cent in 2008 to 16.1 per cent in 2013). Joint and foreign-owned companies have higher shares of employees being trained as compared with local companies: in 2013, 8.1 per cent and 5.5 per cent, respectively. As to other working conditions, such as working time (Table 2.11), males on average are working slightly more hours a week and working overtime more frequently 
Table 2.12 Trade union and gender wage gaps and share of female workers in the workforce, Estonia, 2007-13

\begin{tabular}{llrrrrrrr}
\hline & 2007 & 2008 & 2009 & 2010 & 2011 & 2012 & 2013 \\
\hline Government & Union wage gap & 4.55 & 4.30 & 5.90 & 9.09 & 7.74 & 6.61 & 10.03 \\
and & Gender wage gap & 27.66 & 27.30 & 26.89 & 28.07 & 30.41 & 33.20 & 31.80 \\
municipal & Female workers share, \% & 67.80 & 68.20 & 71.20 & 70.00 & 69.20 & 69.20 & 67.60 \\
$\quad$ companies & & & & & & & & \\
Local & Union wage gap & 5.18 & 5.65 & 17.04 & 13.14 & 28.51 & 27.90 & 8.93 \\
companies & Gender wage gap & 34.80 & 35.49 & 30.57 & 31.93 & 27.38 & 33.35 & 33.72 \\
& Female workers share, \% & 42.00 & 42.10 & 43.10 & 42.60 & 41.50 & 42.10 & 42.20 \\
Joint and & Union wage gap & -11.16 & -23.68 & -14.35 & 11.71 & 9.84 & 22.64 & 34.27 \\
foreign & Gender wage gap & 43.58 & 39.84 & 40.73 & 43.93 & 44.15 & 43.19 & 40.02 \\
companies & & & & & & & & \\
& Female workers share, \% & 48.80 & 46.80 & 48.10 & 48.60 & 47.10 & 47.80 & 47.50 \\
Total & Union wage gap & -2.56 & -4.21 & 5.91 & 11.05 & 11.16 & 13.64 & 13.80 \\
& Gender wage gap & 35.19 & 34.58 & 30.11 & 31.23 & 31.38 & 34.95 & 33.65 \\
& Female workers share, \% & 49.40 & 49.30 & 51.60 & 51.40 & 50.00 & 50.00 & 49.90 \\
\hline
\end{tabular}

Note: $2007-10$ data recalculated from EEK using the Bank of Estonia rate $€ 1=15.6466 \mathrm{kr}$.

Source: Authors' calculations based on the ELFS.

in all ownership types. Working during the weekend is relatively equally distributed in the total sample but there are major differences across the types of companies - in the public sector males work more often at the weekend compared with females, while among local companies the effect is reversed. In addition, some trends are related specifically to foreign companies, such as higher mean working hours a week (by around 1 hour compared with local companies) and less teleworking (for males 11.7 per cent in local companies and 6.7 per cent in foreign-owned companies). These traits could be attributed to the specific sector of their work, different working conditions and the general demands of the employer with regard to job responsibilities.

Finally, Table 2.12 presents average wages for each type of ownership for 2007-13, by union participation and gender. As the results suggest, there exists, in general, both a trade union and a gender wage pay gap, growing through the years and especially noticeable in the local private sector. This is consistent with earlier studies on the trade union effect on wages, where the income disparity increases because trade unions have stronger bargaining power than individuals (Checchi and Garcia-Penalosa 2010), as well as studies of the gender wage gap in the EU (Christofides et al. 2013). An outlier from this case is the result obtained from 2007-09 in foreign companies where average unionised workers' wages were below those of average non-unionised workers. This could be attributed to the relatively small sample size of unionised workers in this category (fewer than 100). It should be noted that the share of female employees in the workforce remains largely stable at around 50 per cent, with the largest share in the public sector.

We next examine the factors that affect the decision to join the union and their relative strength. For that purpose, we have constructed two probit models, the first including the 
Table 2.13 Marginal effects of different factors on the union participation variable, Estonia, 1997-2013

\begin{tabular}{lcc}
\hline Variable & Model 1 & Model 2 \\
\hline Government or municipal ownership (1 if yes) & $0.1261^{* * *}$ & $0.12^{* * *}$ \\
Foreign ownership (1 if yes) & -0.006 & -0.0094 \\
Primary sector (1 if yes) & $-0.0264^{* * *}$ & $-0.0352^{* * *}$ \\
Secondary sector (1 if yes) & -0.0016 & -0.0109 \\
Firm size, 11-19 employees & $0.0096^{* * *}$ & $0.0113^{*}$ \\
Firm size, 20-49 employees & $0.0397^{* * *}$ & $0.0403^{* * *}$ \\
Firm size, 50-99 employees & $0.0524^{* * *}$ & $0.0506^{* * *}$ \\
Firm size, 100-199 employees & $0.0612^{* * *}$ & $0.0722^{* * *}$ \\
Firm size, 200-499 employees & $0.0932^{* * *}$ & $0.0934^{* * *}$ \\
Firm size, 500-999 employees & $0.1255^{* * *}$ & $0.1426^{* * *}$ \\
Firm size, 1000 or more employees & $0.1342^{* * *}$ & $0.1323^{* * *}$ \\
Age & & $0.0081^{* * *}$ \\
Age squared & & $-0.0001^{* * *}$ \\
Male (1 if yes) & & 0.0003 \\
Married (1 if yes) & & -0.0031 \\
Estonian as primary language at home (1 if yes) & & $-0.0244^{* * *}$ \\
Secondary education & & -0.0024 \\
Professional higher education & & 0.0183 \\
Bachelor's degree & & 0.005 \\
Master's degree & & $0.0377^{* *}$ \\
Permanent contract (1 if yes) & & $0.0443^{* * *}$ \\
Pseudo R ${ }^{2}$ & & 0.1906 \\
Prob>chi ${ }^{2}$ & & 0.0000 \\
Number of obs. & 0.1756 & 15639 \\
\hline
\end{tabular}

Notes:

Significant at $* 5 \%, * * 1 \%$ and $* * * 0.1 \%$.

Firm size baseline: 1-10 workers. Education level baseline: primary.

Source: Authors' calculations based on the ELFS.

industry variables (size, indicator variables for primary and secondary sectors, foreign or government) and the second adding the personal variables (age and age squared, gender, marital status, level of education and dummy variables for Estonian as primary language and a regular or permanent contract). We assess the associations based on average marginal effects and construct a table accordingly.

As can be seen from Table 2.13, in line with the previous tables, the biggest influencing factors appear to be the government ownership of a firm that on average is related to a 12.6 per cent higher chance of being in the union in the first model and 12.0 per cent higher chance in the second model. Other significant factors include the firm size with varying but significant at 10 per cent increase in the probability to be in the union for each level increase, age with 0.81 per cent increase on average for each year, having Estonian as the primary language at home and having a permanent contract with 2.44 per cent decrease and 4.43 per cent increase on average, respectively. Education level is 
only significant at 1 per cent in case of the Master's degree dummy variable, on average corresponding to a 3.77 per cent increase in the probability to be in the union compared with the baseline. Foreign ownership effect on union membership is negative but statistically insignificant. One relevant aspect missed by the current study, and found important in the Slovenian study in Chapter 10 of this volume, is that foreign-owned companies may press for decentralisation of collective wage bargaining.

To determine variables that affect wage, we estimated different Mincer wage equations. Once again, we ran several regressions, first including the above-mentioned personal features and union membership, secondly adding the industry or company level variables, and thirdly including extra work place-related variables. We also use two interaction variables, first for being in a union and employed in a foreign company, and second for both being male and employed in a foreign company. The resulting coefficients are presented in the Table 2.14.

From these regressions we can draw a number of conclusions. First, the industry variables have a much greater effect on the wage than do personal characteristics. A model only with variables that describe the individual has low explanatory power. Second, the union membership effect seems to be split between the mere presence of the union at the firm, which on average is associated with 4.6 per cent higher wages, and an individual's trade union membership, which adds an extra 6.1 per cent on average. This seems to be consistent with the coefficients from the second model, where those two effects are not distinguished, but the total effect is close to their sum. On average, 37.5 per cent of workers are trade union members if the union is present at the firm. As expected, foreign ownership, firm size, permanent contract and working overtime are all associated with a higher average wage. Working in either primary or secondary sectors of industry goes together with a lower average wage and the government ownership effect is not significant. Finally, one of the interaction variables is significant; working in a foreign-owned company is linked, on average, to a 13.92 per cent wage premium for females and 27.42 per cent for males, totalling to a twofold difference.

In the interviews with the Estonian social partners, comments were made on the role of foreign-owned enterprises in the Estonian labour market. It seems that they often adapt their labour standards to those of the host country rather than attempt to maintain the higher labour standards applied at home, though there are also positive cases (Peterson 2018). For example, similar to elsewhere - such as Volkswagen subsidiaries in Poland - local Estonian subsidiaries support the whole group with wages that do not rise along with productivity gains. This applies, for example, to Rakvere Meat Processing, a subsidiary of the Finnish manufacturer HKScan Oyj, whose industrial conflict, mainly concerning wages, has received substantial attention. According to the president of the Estonian Employers' Confederation the industrial dispute at Rakvere was a sign of management problems at a particular company because the wage level was higher than the median (Tamsar 2018). Tamsar (2018) also drew attention to the danger that Estonian subsidiaries of multinationals could be threatened by wage increases as it is easy to relocate production into countries with lower wage costs, especially because of the situation of local subsidiaries in global value chains, characterised by a shortage of own product development. Finally, we should keep in mind that despite the many potentially positive effects of FDI, for example, the effects of knowledge and capital transfer on higher productivity and wages, they may also exacerbate labour market inequalities, as 
Table 2.14 Coefficients for the Mincer-like earnings regression, Estonia, 1997-2013

\begin{tabular}{|c|c|c|c|}
\hline Variable & Model 1 & Model 2 & Model 3 \\
\hline Union membership ( 1 if yes) & $0.3113^{* * *}$ & $0.1013^{* * *}$ & $0.0607 * * *$ \\
\hline Union presence ( 1 if yes) & & & $0.0463 * * *$ \\
\hline Both in union and foreign ownership ( 1 if yes) & & -0.1148 & -0.0906 \\
\hline Both male and foreign ownership ( 1 if yes) & & $0.1485^{* * *}$ & $0.135 * * *$ \\
\hline 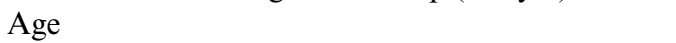 & $0.0657 * * *$ & $0.0662 * * *$ & $0.0378^{* *}$ \\
\hline Age squared & $-0.0009^{* * *}$ & $-0.0008 * * *$ & $-0.0005^{* * *}$ \\
\hline Male (1 if yes) & $0.411 * * *$ & $0.3808^{* * *}$ & $0.3138 * * *$ \\
\hline Married ( 1 if yes) & $0.1318^{* * *}$ & $0.0389 * * *$ & $0.0377 * * *$ \\
\hline Estonian as a primary language at home ( 1 if yes) & $0.2074 * * *$ & $0.2131 * * *$ & $0.1876^{* * *}$ \\
\hline Secondary education & $0.087 * * *$ & $0.0765^{* * *}$ & $0.0782 * * *$ \\
\hline Professional higher education & $0.1833^{* * *}$ & $0.3967 * * *$ & $0.3307 * * *$ \\
\hline Bachelor degree & $0.4616^{* * *}$ & $0.4532 * * *$ & $0.4345^{* * *}$ \\
\hline Master's degree & $0.3097 * * *$ & $0.5936^{* * *}$ & $0.5319 * * *$ \\
\hline Foreign ownership ( 1 if yes) & & $0.1627 * * *$ & $0.1392 * * *$ \\
\hline Governmental or municipal ownership ( 1 if yes) & & 0.0127 & 0.0142 \\
\hline Firm size, 11-19 employees & & $0.1304 * * *$ & $0.1003 * * *$ \\
\hline Firm size, 20-49 employees & & $0.1908 * * *$ & $0.1604 * * *$ \\
\hline Firm size, 50-99 employees & & $0.2177 * * *$ & $0.1695 * * *$ \\
\hline Firm size, 100-199 employees & & $0.2882 * * *$ & $0.2355 * * *$ \\
\hline Firm size, 200-499 employees & & $0.3149 * * *$ & $0.257 * * *$ \\
\hline Firm size, 500-999 employees & & $0.3507 * * *$ & $0.2881 * * *$ \\
\hline Firm size, 1000 or more employees & & $0.3931 * * *$ & $0.3051 * * *$ \\
\hline Primary sector ( 1 if yes) & & $-0.0833 * * *$ & $-0.1313^{* * *}$ \\
\hline Secondary sector ( 1 if yes) & & $-0.0735 * * *$ & $-0.1027 * * *$ \\
\hline Number of working hours per week & & & $0.0311 * * *$ \\
\hline Working overtime ( 1 if yes) & & & $0.0596 * *$ \\
\hline Working during the weekends ( 1 if yes) & & & $-0.1054 * * *$ \\
\hline Teleworking ( 1 if yes) & & & $0.1405^{* * *}$ \\
\hline Permanent contract ( 1 if yes) & & & $0.0551 * * *$ \\
\hline Being trained in the last month ( 1 if yes) & & & $0.1553 * * *$ \\
\hline $\mathrm{R}^{2}$ & 0.0564 & 0.3283 & 0.4664 \\
\hline Number of obs. & 35766 & 13007 & 13006 \\
\hline
\end{tabular}

Notes:

Significant at $* 5 \%, * * 1 \%$ and $* * * 0.1 \%$.

Firm size baseline: 1-10 workers. Education level baseline: primary.

Source: Author's calculations based on the ELFS.

demonstrated by Vahter and Masso (2018) with regard to the possible positive impact of FDI on the gender pay gap; they analysed both cross-sectional data and the effects of foreign takeovers. The latter shows that the effects of FDI on economic and social convergence need not be straightforward. 


\subsection{Conclusion}

The influence of multinational companies is one factor explaining why there is a difference between economic and social convergence. While there is no doubt that the Baltic states have benefited greatly from the inflow of FDI and, generally, multinationals are good employers, it is also clear that their presence is related to some inequalities, such as the gender pay gap. While more extensive social dialogue might be one answer, it is not certain that it would follow automatically, given the low unionisation among both local and foreign-owned companies, the limited effect on wages and some anecdotal evidence of disputes with unions in multinational companies. Thus, the results of our case study bear some resemblance to the results of the Slovenian case study (Chapter 10 in this volume), namely, that differences between domestic and foreign-owned companies are not always evident - that is, foreign-owned companies generally bring neither better nor worse standards - and that foreign-owned companies tend to adapt to the local market with regard to social dialogue practices. However, Bembič (Chapter 10 in this volume) also notes that foreign-owned companies are more careful in following legislation and collective agreements. Bembič also stresses the importance of distinguishing between company-level effects and national effects within the framework of efforts to provide an environment attractive for foreign capital (see Chapter 10 in this volume). As to the challenges posed by FDI, international cooperation with unions in abroad may help, for example, by putting pressure on foreign-owned companies via their home country unions, a tactic that has been used in both Estonia and Slovenia (Bembič in Chapter 10 of this volume).

\section{CONCLUSIONS}

The case of the Baltic states is positive at least in some aspects of convergence: during the past 20 years, economic growth has been substantial and, even though there are also some imbalances such as the growth rates of profits in contrast to wages, it is reflected positively in many social indicators and has benefited most of the population. However, developments to date also illustrate that not all the differences between European countries as regard social and labour market indicators are likely to diminish simply owing to income convergence. Furthermore, as our case studies on migration and foreign-owned enterprises show, the particular mechanisms through which convergence may occur may also pose some challenges.

One such challenge is social dialogue. The Baltic states as a group have an (economic) liberal social model, even though there have been some positive developments, such as increasing the number of sectoral collective agreements in Lithuania, from one or two branch agreements ten years ago to around 40 currently (information from Egle Radisauskiene, Deputy Minister of Social Security and Labour, Lithuania). Despite the passage of more than 25 years since the transition to a market economy and the restoration of capitalism, we can see behind the trade unions' weakness certain path-dependency effects owing to the Soviet legacy; under the Soviet economy unions played a different role, encouraging unrealistic expectations among the older workforce, although there is some limited anecdotal evidence that attitudes may be different among 
younger employees. Assistance from abroad for capacity-building for the social partners may be helpful in developing social dialogue. Compared with other countries, in the context of the Baltic states some additional topics are important, such as migration and industrial relations in foreign-owned enterprises. Thus the importance of foreign-owned enterprises in the Baltic states is another reason why industrial relations should operate across borders.

Given the state of social dialogue until now, it is not surprising that we could not find many cases in the Baltic states in which social dialogue had a positive effect on social convergence. The recent minimum-wage increases in Estonia that have reduced wage inequalities, but possibly also contributed towards increasing net migration flows, may be one instance. Despite some natural differences between the views of the social partners, there seems to be a common understanding that social and economic convergence are closely linked, and that some changes are needed in the existing business model based on comparatively cheap labour costs (Peterson 2018). In many economic and social convergence indicators Estonia is performing better, not only with regard to incomes, but also wages, inequalities, working-time and employment rates. However, we should be wary of attributing too many of these differences to social dialogue as the general economic performance of the three Baltic states is probably more significant. Anyway, a balance is needed between economic policies and their social context.

We have discussed various topics that future social dialogue should address, such as how to make use of the Baltic states' diaspora (although our case study focused on Latvia, in the social partners' view it is also relevant to Lithuania, which has similarly high rates of outward migration), either through return migration or other means; how to cope with labour shortages and ensure the upgrading of skills, making full use of the highly educated populations. Better availability of indicators for benchmarking purposes may also help to widen attention, since the focus so far has mainly been on incomes. Future efforts to improve social convergence should pay attention to the emerging new forms of work and new sectors, such as the so-called 'sharing economy', in which Estonia is leading the way in some areas. For instance, in connection with the Swedish industrial relations model it has been emphasised that it contributes to ensuring acceptance of technological changes on the side of the workforce. As in other countries, however, local national contexts should be considered and there is no 'one-size-fits-all' policy. Thus we should be cautious of transferring particular approaches used in countries with high levels of collective bargaining and union density to countries such as the Baltic states, where to date more modest levels have prevailed.

\section{NOTES}

1. The term 'middle-income trap' refers to the phenomenon of rapidly growing economies stagnating at middle-income levels and thus failing to become high-income countries (Aiyar et al. 2013).

2. A separate analysis of wage and income convergence shows their similar behaviour (Gopinath and Chen 2003; Ezcurra and Pascual 2005).

3. Life expectancy at a certain age is the mean additional number of years that a person of that age can expect to live, if subjected throughout the rest of his or her life to the current mortality conditions (agespecific probabilities of dying, that is, the death rates observed for the current period) (source: Eurostat).

4. There seems to be no uniform definition of labour shortages, but generally it refers to a situation in which there is an insufficient number of candidates to fill existing vacancies at the wages offered. As elsewhere, 
the ageing population in the Baltics is contributing to this, but so is outward labour migration, especially since EU accession in 2004.

5. In Estonia the quota system to regulate immigration has been in place since the 1990s. In recent years the annual immigration quota has been set at 0.1 of Estonia's permanent population. As the existing system has been considered too restrictive, a discussion has started with the social partners on alternative policy solutions (Maasing and Asari 2017).

6. In 2014, the public education expenditure share of GDP in Estonia was 4.9 per cent, in Latvia 5.3 per cent and in Lithuania 4.4 per cent, while in Sweden it was 7.1 per cent and in Norway 7.7 per cent (Eurostat).

7. The idea that social standards and policies in Europe can fully converge is commonly referred to as the European social model (Hodge and Howe 1999). This vision is challenged by problems such as the disproportion between the number and potency of economic and social policies (social policies are very much the poor cousins of the former), the reduced power of national legislation (limited by EU directives) and great variation in the economic development of different countries (Scharpf 2002). The last mentioned poses the greatest barrier to convergence. Draxler and van Vliet (2010) observed considerable variety in social policies, particularly in central and eastern European countries. With the exception of health-care policies, which are uniform among the new member states, but still differ from those in western Europe, and the newly adopted three-pillar pension model, other key aspects of the social protection systems, such as the unemployment benefit period, have not undergone convergence. In the study, they analyse total social expenditure as a percentage of GDP during 2000-2006 and find two distinct patterns of convergence, one for the EU15 and one for the new member states. This confirms the existence of at least one separate model for the central and eastern European countries and further proves why the European social model might not be the best for such an analysis.

8. A detailed review of the evolution of various industrial relations indicators can be found in Masso et al. (2018). Korkut et al. (2017) argued that union density in central and eastern European countries is likely to increase because in most of them the outward migration of non-union workers is not accompanied by an equivalent immigration.

9. Other terms applicable here are 'platform economy' and 'gig economy' (Kilhoffer et al. 2017).

10. That is, not only the 'sharing' platform generates the revenue, but also the person that uses the platform to supply his or her services (for example, the sums of money paid for accommodation or transportation are not included here).

11. Aivar Kotka, head of the Economic Committee, explained that 'transportation by agreement' is a new form of public transport. The main difference between 'transportation by agreement' and taxi transportation is that people can order 'transportation by agreement' only via an electronic platform and pay only electronically. Unlike taxis, the car providing a 'transportation-by-agreement' service is not marked as such and no tools to calculate the cost of the ride are required ('Transportation by agreement versus taxi service: what is the difference?' 2016).

12. 'Sharing economy' refers to a business model in which economic activities are facilitated by collaborative platforms, which create a marketplace for temporary use of 'underexploited' goods or services (Eijas-Taal et al. 2016).

13. Groups facing a similar situation include creative persons and people who have signed a civil law contract (not a labour contract).

14. In Estonia, health insurance is provided for all people registered with the Unemployment Insurance Fund as unemployed.

15. Upon entering into a contract, insurance premiums must be paid to the Health Insurance Fund. Typically, a voluntary insurance contract is concluded for one year. The following persons are entitled to enter into a contract: (1) people who two months prior to entering into a contract have been insured for at least 12 months through an employer, as a recipient of employment or service fees under a contract under the Law of Obligations, a member of a directing or controlling body of a legal entity, a sole proprietor, a pupil or a student; (2) a person who has paid for insurance himself or herself, or for whom social tax has been paid while employed under a contract under the Law of Obligations with a contract of employment or contract of service under the Law of Obligations, while under contract of management or a controlling body, as a sole proprietor or a spouse of a sole proprietor in the calendar year preceding the conclusion of the contract at least twelve times calculated from the monthly rate established by the state budget for the fiscal year. More information can be found at https://www.haigekassa.ee/en/people/health-insurance/ voluntary-insurance (accessed 14 January 2019).

16. We understand social dialogue with the International Labour Organization (ILO) as 'all types of negotiation, consultation or simply exchange of information between, or among, representatives of governments, employers and workers, on issues of common interest relating to economic and social policy' (ILO 2017).

17. These are all areas that will be included in the new 'Strategy for attracting Latvian diaspora to be involved in the work of the Latvian Investment and Development Agency for 2017-2020' (Investment and 
Development Agency of Latvia 2017); this includes, for example, investment leads, mentoring of young entrepreneurs in Latvia, diaspora tourism.

18. Established by the Guidelines for National Identity, Civil Society and Integration Policy 2012-2018 (NIPSIPP) Implementation Supervisory Board.

19. Currently the 'old diaspora' (those who emigrated during the war and their descendants) is the most active in these organisations.

20. However, the linkage between FDI and inequality is not unambiguous; for instance, different researchers have found signs of both decrease (Balcioglu 2016) and increase (Gopinath and Chen 2003) in the wage gap between unskilled and skilled labour as a result of FDI inflow.

\section{REFERENCES}

Adam, F., P. Kristan and M. Tomšič (2008), 'Between neo-liberalism and neo-corporatism: Estonia and Slovenia in the comparative perspective', Revija Za Socijalnu Politiku, 15 (2), 135-50.

Adams-Kane, J., C. Lopez and J. Wilhelmus (2016), 'Cross-border investment in Europe: from macro to financial data', MILKEN Institute, accessed 9 August 2018 at https://assets1b.milken institute.org/assets/Publication/ResearchReport/PDF/CrossBorderInvestment-Milken-Institute. pdf.

Aidukaite, J. (2006), 'The formation of social insurance institutions of the Baltic States in the postsocialist era', Journal of European Social Policy, 16 (3), 259-70.

Aikins, K. and N. White (2011), Global Diaspora Strategies Toolkit: Diaspora Matters, Dublin: Diaspora Matters.

Aiyar, S., R. Duval, D. Puy, Y. Wu and L. Zhang (2013), 'Growth slowdowns and the middleincome trap', IMF Working Paper No. WP/13/71, International Monetary Fund.

AMECO (annual macroeconomic) database, accessed 21 December 2018 at https://ec.europa. eu/info/business-economy-euro/indicators-statistics/economic-databases/macro-economic-data base-ameco/ameco-database_en.

Anspal, S. (2015), 'Essays on gender wage inequality in the Estonian labour market', PhD dissertation, Faculty of Economics and Business Administration, University of Tartu, Estonia.

Anxo, D. (2018), Data on working time in European countries based on European Working Conditions Survey data and the European Labour Force Survey Data, personal communication.

Atoyan, R., L. Christiansen, A. Dizioli, C. Ebeke, N. Ilahi, A. Iliyna, et al. (2016), 'Emigration and its economic impact on Eastern Europe', IMF Staff Discussion Note No. SDN/16/07, International Monetary Fund.

Balcioglu, H. (2016), 'Multinational companies and wage inequality in the host country: the case study of Turkey', International Journal of Economic Perspectives, 10 (4), 406-15.

Barro, R. and X. Sala-i-Martin (2004), Economic Growth, Cambridge, MA: MIT Press.

Birka, I. (2016), 'Ministru prezidenta diasporas uzñēmēju konsultatîvās padomes locekḷu interviju pārskats', unpublished report, containing interviews with members of the Consultative Council of the Diaspora, Advisory Council of Diaspora Entrepreneurs.

Burduli, A. (2017), 'Income convergence performance within the EU before and after the first eastward 2004 enlargement', Master's thesis, School of Economics and Business Administration, University of Tartu, Estonia.

Cabinet of Ministers of the Republic of Latvia (2013), 'About the Return Migration Support Action Plan 2013-2016', Direction N.356 of the Cabinet of Ministers of the Republic of Latvia, accessed: 21 December 2018 at https://likumi.lv/doc.php?id=258715.

Campos, N.F. and A. Dabušinskas (2009), 'So many rocket scientists, so few marketing clerks: estimating the effects of economic reform on occupational mobility in Estonia', European Journal of Political Economy, 25 (2), 261-75.

Campos, N.F., F. Coricelli and L. Moretti (2014), 'Economic growth and political integration: estimating the benefits from membership in the European Union using the synthetic counterfactuals method', IZA Discussion Paper No. 8162, Institute of Labor Economics. 
Checchi, D. and C. Garcia-Penalosa (2010), 'Labour market institutions and the personal distribution of income in the OECD', Economica, 77 (307), 413-50.

Cho, S.-W. and J.P. Diaz (2018), 'Skill premium divergence: the roles of trade, capital and demographics', Economic Theory, doi:10.1007/s00199-018-1098-8.

Christofides, L., A. Polycarpou and K. Vrachimis (2013), 'Gender wage gaps, "sticky floors" and "glass ceilings" in Europe', Labour Economics, 21 (2), 86-102.

Docquier, F., Ç. Ozden and G. Peri (2014), 'The labour market effects of immigration and emigration in OECD countries', Economic Journal, 124 (579), 1106-45.

Draxler, J. and O. van Vliet (2010), 'European social model: no convergence from the east', Journal of European Integration, 32 (1), 115-35.

Eamets, R. and E. Kallaste (2004), 'The lack of the wage setting power of Estonian trade unions?', Baltic Journal of Economics, 5 (1), 44-60.

Eesti Haigekassa (2018), 'Voluntary insurance', accessed 20 February 2018 at https://www.haige kassa.ee/en/people/health-insurance/voluntary-insurance.

Eljas-Taal, K., K. Rõa, A. Lauren, J. Vallistu and K. Müürisepp (2016), 'Implementing the shared economy principles in Estonian economic and legal system', Ministry of Economic Affairs and Communication, accessed 20 February 2018 at https://www.mkm.ee/sites/default/files/lopparu anne.pdf (in Estonian, summary in English).

Estonian Labour Force Survey, accessed 22 December 2018 at https://www.stat.ee/labour-market.

Eurobarometer (2017), 'Public opinion in the European Union', accessed 9 August 2018 at file://C:/Users/User/Downloads/eb88_data_annex_en\%20\%20(1).pdf.

European Central Bank (2012), 'Monthly bulletin 04', accessed 9 August 2018 at https://www.ecb. europa.eu/pub/pdf/mobu/mb201204en.pdf.

European Economic and Social Committee (EESC) (2017), 'Member States should regulate new forms of employment and guarantee access to social security, says EESC', 20 December, accessed 22 December 2018 at http://www.eesc.europa.eu/en/news-media/news/members-statesshould-regulate-new-forms-employment-and-guarantee-access-social-security-says-eesc.

European Working Conditions Survey, accessed 21 December 2018 at https://www.eurofound. europa.eu/surveys/european-working-conditions-surveys.

Eurostat, accessed 21 December 2018 at https://ec.europa.eu/eurostat.

Eurostat Structure of Earnings Survey, accessed 21 December 2018 at https://ec.europa.eu/ eurostat/web/microdata/structure-of-earnings-survey.

Ezcurra, R. and P. Pascual (2005), 'Is there convergence in income inequality levels among the European regions?', Applied Economics Letters, 12 (12), 763-7.

Faro, A.L. (2012), 'Bargaining in the shadow of "optional frameworks"? The rise of transnational collective agreements and EU law', European Journal of Industrial Relations, 18 (2), 153-65.

Ferraro, S., J. Meriküll and K. Staehr (2018), 'Minimum wages and the wage distribution in Estonia', Applied Economics, 50 (49), 5253-68, doi:10.1080/00036846.2018.1486017.

Fries-Tersch, E., T. Tugran, L. Rossi and H. Bradley (2018), '2017 annual report on intra-EU labour mobility', accessed 9 August 2018 at file:///C:/Users/User/Downloads/Intra-EU\%20 labour\%20mobility\%202017.pdf.

Galgóczi, B. and E. Mermet (2003), 'Wage developments in candidate countries', Transfer, 9 (1), $50-63$.

Glassner, V. (2013), 'Central and eastern European industrial relations in the crisis: national divergence and path-dependent change', Transfer, 19 (2), 155-69.

Gopinath, M. and W. Chen (2003), 'Foreign direct investment and wages: a cross-country analysis', Journal of International Trade and Economic Development, 12 (3), 285-309.

Haque, N.U. and S.J. Kim (1995), 'Human capital flight: impact of migration on income and growth', IMF Staff Papers, 42 (3), 577-607.

Hauschildt, K., C. Gwosć, N. Netz and S. Mishra (2015), Social and Economic Conditions of Student Life in Europe. Eurostudent V 2012-2015: Synopsis of Indicators, Bielefeld: W. Bertelsmann Verlag.

Hazans, M. (2016a), 'Migration experience of the Baltic countries in the context of economic crisis', in M. Kahanec and K.F. Zimmermann (eds), Labor Migration, EU Enlargement, and the Great Recession, Berlin and Heidelberg: Springer, pp. 297-344. 
Hazans, M. (2016b), 'Atgriešanās Latvijā: remigrantu aptaujas rezultāti. LU Diasporas un migrācijas pētijumu centrs' ('Returning to Latvia: results of the survey of return migrants'), accessed 20 February 2018 at https://www.diaspora.lu.lv/fileadmin/user_upload/lu_portal/pro jekti/diaspora/petijumi/Atgriesanas_Latvija___petijuma_zinojums_FINAL03.pdf.

Hazans, M. and K. Philips (2009), 'The post-enlargement migration experience in the Baltic labor markets', in M. Kahanec and K.F. Zimmermann (eds), EU Labor Markets After PostEnlargement Migration, Berlin and Heidelberg: Springer, pp. 255-304.

Hodge, S. and J. Howe (1999), 'Can the European social model survive?', European Urban and Regional Studies, 6 (2), 178-84.

Hofstede Insights (2018), 'Compare countries', accessed 21 March 2018 at https://www.hofstedeinsights.com/product/compare-countries/.

International Labour Office (ILO) (2017), 'Social dialogue. Finding a common voice', accessed 22 March 2018 at http://www.ilo.org/public/english/dialogue/download/brochure.pdf.

International Monetary Fund (IMF) (2015), 'Republic of Estonia, 2015', IMF Country Report No. 15/337, International Monetary Fund.

Investment and Development Agency of Latvia (2017), 'Latvijas diasporas piesaistes stratēgija Latvijas investīciju un attīstības ağentūras funkciju īstenošanai 2017.-2020.gadam' ('Strategy for attracting Latvian diaspora to be involved in the work of the Latvian Investment and Development Agency for 2017-2020'), unpublished draft document by the Investment and Development Agency of Latvia.

Iwasaki, I. and K. Kumo (2018), 'J-curve in transition economies: a large meta-analysis of the determinants of output changes', Comparative Economic Studies, 60 (forthcoming).

Jefferys, S. (2010), “Transfert du modèle social ou "dumping social”? Les relations professionnelles dans des multinationales françaises des services en Europe de l'Est' ('Country-of-origin transfers or "social dumping?" French service sector employment relations in Central and Eastern Europe'), Travail et Emploi, 3 (123), 9-26.

Johanson, A. (2017), 'Estonia's open migration policy surprising even in Europe', accessed 9 August 2018 at https://news.postimees.ee/4036007/estonia-s-open-migration-policy-surprising-ev en-in-europe.

Kilhoffer, Z., K. Lenaerts and M. Beblavy (2017), 'The platform economy and industrial relations: applying the old framework to the new reality', CEPS Research Report No. 2017/12, Centre for European Policy Studies, Brussels.

Korkut, U., A. de Ruyter, M. Maganaris and D. Bailey (2017), 'What next for unions in Central and Eastern Europe? Invisibility, departure and the transformation of industrial relations', European Journal of Industrial Relations, 23 (1), 65-80.

Kose, M.A., E.S. Prasad and M.E. Terrones (2005), 'Growth and volatility in an era of globalization', IMF Staff Papers, 52 (suppl. 1), 31-63.

Krings, T. (2009), 'A race to the bottom? Trade unions, EU enlargement and the free movement of labour', European Journal of Industrial Relations, 15 (1), 49-69.

Kriz, K., J. Meriküll, A. Paulus and K. Staehr (2008), 'Why do individuals evade payroll and income taxation in Estonia?', in M. Pickhardt and E. Shinnick (eds), Shadow Economy, Corruption and Governance, Cheltenham, UK and Northampton, MA, USA: Edward Elgar, pp. 240-64.

Kuokštis, V. (2011), 'What type of capitalism do the Baltic countries belong to?', EMECON, (1), accessed 22 March 2018 at https://ssrn.com/abstract=2083832.

Leitner, S. and R. Römisch (2015), 'Economic and social convergence in the EU: a policy note', GRINCOH Working Paper No. 1.13, Growth-Innovation-Competitiveness: Fostering Cohesion in Central and Eastern Europe (GRONCOH) Project.

Lessmann, C. (2013), 'Foreign direct investment and regional inequality: a panel data analysis', China Economic Review, 24 (1), 129-49.

'Letter of explanation on the amendment of the Public Transport Act' ('Ühistranspordiseaduse muutmise seaduse eelnõu seletuskiri') (2016), accessed 20 February 2018 at http://g.delfi.ee/ images/pix/kokkuleppevedu-73710767.pdf.

Levenko, N., K. Oja and K. Staehr (2017), 'Total factor productivity growth in central and eastern Europe before, during and after the Global Financial Crisis', Eesti Pank Working Paper 8/2017, Bank of Estonia. 
Lévesque, C., M.-A. Hennebert, G. Murray and R. Bourque (2016), 'Corporate social responsibility and worker rights: institutionalizing social dialogue through international framework agreements', Journal of Business Ethics, 1-16, doi:10.1177/0143831X18776423.

LSM (2017), 'CSP: Latvijā augstākais sieviešu - vadītāju rādītājs Eiropas Savienībā’ ('CSB [Central Statistical Bureau]: Latvia - the highest proportion of women among managers in the European Union'), accessed 25 November 2018 at https://www.lsm.lv/raksts/zinas/latvija/csp-latvija-augs takais-sieviesu-vaditaju-raditajs-eiropas-savieniba.a254129/.

Maasing, H. and E.M. Asari (2017), 'Evolution of migration policy in the European Union and Estonia', Estonian Human Development Report 2016/2017, Estonia at the Age of Migration, Cooperation Assembly Foundation, accessed 16 March 2018 at https://inimareng.ee/en/migra tion-and-demographic-changes-in-estonia-and-europe/evolution-of-migration-policy-in-the-eur opean-union-and-estonia/.

Marginson, P. and G. Meardi (2007), 'European Union enlargement and the foreign direct investment channel of industrial relations transfer', Industrial Relations Journal, 37 (2), 92-110.

Marginson, P. and G. Meardi (2009), 'Multinational companies and collective bargaining', European Foundation for the Improvement of Living and Working Conditions, accessed 9 August 2018 at https://www.eurofound.europa.eu/sites/default/files/ef_files/docs/eiro/tn090404 9s/tn0904049s.pdf.

Masso, J. and K. Krillo (2011), 'Mixed adjustment forms and inequality effects in Estonia, Latvia and Lithuania', in D. Vaughan-Whitehead (ed.), Work Inequalities in the Crisis: Evidence from Europe, Cheltenham, UK and Northampton, MA, USA: Edward Elgar and Geneva: ILO, pp. 35-98.

Masso, J. and T. Paas (2007), 'Social protection systems and labour market policies in the Baltic states', in T. Paas and R. Eamets (eds), Labour Market Flexibility, Flexicurity and Employment: Lessons of the Baltic States, Hauppauge, NY: Nova Science, pp. 143-81.

Masso, J., K. Espenberg and I. Mierina (2015), 'The Baltic states: convergence with the European social model or further liberalization?', in D. Vaughan-Whitehead (ed.), The European Social Model in Crisis: Is Europe Losing its Soul?, Cheltenham, UK and Northampton, MA, USA: Edward Elgar and Geneva: ILO, pp. 66-120.

Masso, J., Espenberg, K. and Mierina, I. (2016), 'Is the world of work stimulating middle class growth in the Baltic states?', in D. Vaughan-Whitehead (ed.), Europe's Disappearing Middle Class?: Evidence from the World of Work, Cheltenham, UK and Northampton, MA, USA: Edward Elgar and Geneva: ILO.

Masso, J., K. Espenberg, A. Masso, I. Nierina and K. Philips (2014), 'Between economic growth and social justice: different inequality dynamics in the Baltic states', in B. Nolan, W. Salverda, D. Checchi, I. Marx, A. McKnight, I.G. Toth, et al. (eds), Changing Inequalities and Societal Impacts in Rich Countries. Thirty Countries' Experiences, Oxford: Oxford University Press, pp. $96-125$.

Masso, J., J. Meriküll and P. Vahter (2013), 'Benefits of distributed profit taxation versus gross profit taxation: are there effects on firms?', Journal of Comparative Economics, 41 (4), 1092-105.

Masso, J., M. Tverdostup, I. Mierina and K. Espenberg (2018), 'Labour market inequalities in conditions of limited social dialogue: the case of the Baltic states', in D. Vaughan-Whitehead (ed.), Inequalities in World of Work: What Role for Industrial Relations and Social Dialogue, EC/ ILO conference volume.

McCann, P. (2013), Modern Urban and Regional Economics, Oxford: Oxford University Press.

Meardi, G. (2006), 'Multinationals' heaven? Uncovering and understanding worker responses to multinational companies in post-communist Central Europe', International Journal of Human Resource Management, 17 (8), 1366-78.

Meardi, G. (2012), Social Failures of EU Enlargement: A Case of Workers Voting with Their Feet, New York: Routledge.

Meardi, G., M. Fichter, M. Frybes, P. Marginson, M. Stanojevic and A. Tóth (2005), 'Varieties of multinationals', paper presented at the Seventh Conference of the European Sociological Association, Toruń, Estonia, 9-12 September.

Meardi, G., S. Strohmer and F. Traxler (2010), 'The social transfers of multinationals in Central Europe: British, US, Austrian and German experiences reviewed', in S. Contrepois, V. Delteil, 
P. Dieuaide and S. Jefferys (eds), Globalizing Employment Relations: Multinational Firms and Central and Eastern Europe Transitions, London: Palgrave Macmillan, pp. 29-44.

Mierina, I. (ed.) (2015), Latvijas emigrantu kopienas: cerību diaspora (The Emigrant Communities of Latvia: Diaspora of Hope), Riga: LU Filozofijas un Sociologijas institūts.

Mierina, I., L. Ose, A. Lāce and M. Kaprāns (2017b), 'Vienojošas nacionālās identitātes un Latvijas kultūrtelpas nostiprināšana. Priekšlikumi sabiedrības integrācijas politikas plānam 2019-2025. gadam' ('Strengthening the unifying national identity and Latvian cultural space. Proposals for the plan for the integration of society from 2019 to 2025'), accessed 20 February 2018 at https://www.km.gov.lv/uploads/ckeditor/files/Sabiedribas_integracija/Petijumi/Ekspertu\%20zi nojums $\% 20$ vienojosas $\% 20$ nacionalas $\% 20$ identitates $\% 20$ un $\% 20$ kulturtelpas $\% 20$ nostiprinasanai. pdf.

Mieriṇa, I., I. Ulnicāne, A. Vingre, L. Bužinska and A. Van der Steina (2017a), 'Diasporas zinătnieku piesaiste un sadarbỉbas veicināšana' ('Promoting cooperation and involvement of diaspora scientists'), LU DMPC, Riga, accessed 20 February 2018 at https://www.diaspora.lu.lv/ fileadmin/user_upload/lu_portal/projekti/diaspora/petijumi/Zinojums_zinatnieki_ar_kopsavil kumu.pdf.

Naz, A., N. Ahmad and A. Naveed (2017), 'Wage convergence across European regions: do international borders matter?' Journal of Economic Integration, 32 (1), 35-64.

Organisation for Economic Co-operation and Development (OECD) (2012), 'OECD economic surveys: Estonia 2012', OECD, doi:10.1787/eco_surveys-est-2012-en.

Organisation for Economic Co-operation and Development (OECD) (2017a), 'OECD economic surveys: Estonia 2017', OECD, accessed 25 November 2018 at https://www.oecd.org/economy/ surveys/Estonia-2017-OECD-economic-survey-overview.pdf.

Organisation for Economic Co-operation and Development (OECD) (2017b), 'International migration outlook 2017', OECD, accessed: 9 August 2018 at http://medienservicestelle.at/migra tion_bewegt/wp-content/uploads/2017/10/International_Migration_Outlook_2017.pdf.

Organisation for Economic Co-operation and Development (OECD) (2018), 'PISA 2015. Results in focus', OECD, accessed 25 November 2018 at https://www.oecd.org/pisa/pisa-2015-results-infocus.pdf.

Organisation for Economic Co-operation and Development (OECD) (n.d.), 'FDI stocks', accessed 22 October 2018 at https://data.oecd.org/fdi/fdi-stocks.htm\#indicator-chart.

Osila, L. (2012), 'Government refuses to reduce unemployment insurance premiums', European Industrial Relations Observatory, accessed: 22 March 2018 at http://www.eurofound.europa.eu/ eiro/2011/12/articles/ee1112019i.htm.

Ost, D. (2000), 'Illusory corporatism in eastern Europe: neoliberal tripartism and post-communist class identities', Politics \& Society, 28 (4), 503-30.

PBLA (World Federation of Free Latvians) (2016), 'Diasporas padomes pārstāvis piedalās Nacionālās attīstības padomes sēdē ('Representative of the Diaspora Council participates in the meeting of the National Development Council'), accessed: 20 February 2018 at http://www. reitingi.lv/lv/news/sabiedriba/111539-diasporas-padomes-parstavis-piedalas-nacionalas-attistib as-padomes-sede.html.

Peterson, P. (2018), Personal interview, Tartu, Estonia, 11 January.

Pollert, A. (2000), 'Ten years of post-communist central and eastern Europe: labour's tenuous foothold in the regulation of the employment relationship', Economic and Industrial Democracy, 21 (2), 183-210.

Pruchnik, K. and J. Zowczak (2017), 'How not to get stuck in the middle lessons for the Commonwealth of Independent States from central and eastern Europe', CASE Working Paper No. 6 (130), Center for Social and Economic Research, Warsaw.

Putniňš, T. and A. Sauka (2011), 'Size and determinants of shadow economies in the Baltic states', Baltic Journal of Economics, 11 (2), 5-25.

Putninš, T.J. and A. Sauka (2017), 'Shadow economy index for the Baltic countries 2009-2016', technical report, Centre for Sustainable Business, Stockholm School of Economics (SSE) Riga.

Ramey, G. and V. Ramey (1995), 'Cross-country evidence on the link between volatility and growth', American Economic Review, 85 (5), 1138-50. 
Scharpf, F.W. (2002), 'The European social model: coping with the challenges of diversity', Journal of Common Market Studies, 40 (4), 645-70.

SKDS (Market and Public Opinion Research Center) (2016), 'Attieksme pret Pasaules Brivo latviešu apvienību. Latvijas iedzīvotāju aptauja' ('Attitude of the Latvian inhabitants towards the World Federation of Free Latvians'), report, SKDS, Riga.

Smętkowski, M. and P. Wójcik (2012), 'Regional convergence in Central and Eastern European countries: a multidimensional approach', European Planning Studies, 22 (6), 923-39.

Staehr, K. (2015), 'Economic growth and convergence in the Baltic states: caught in a middleincome trap?', Intereconomics, 50 (5), 274-80.

Statistics Estonia database, accessed 21 December 2018 http://pub.stat.ee/px-web.2001/dialog/ statfile1.asp.

Šūpule, I., L. Apine, L. Salmina, I. Karklina and L. Krieke (2016), Remigrācijas politika Eiropā un citās valstīs. LU Diasporas un migräcijas pētījumu centrs (Return Migration Policy in Europe and Other Countries), Riga: LU Akadēmiskais apgāds.

Tamsar, T. (2018), Personal interview, Tallinn, Estonia, 3 January.

Tang, N. and C. Cousins (2005), 'Working time, gender and family: an east-west European comparison', Gender, Works and Organisation, 12 (6), 527-50.

Tóth, A. (1999), 'Building union organisation at autotransplants in Hungary', in J. Waddington (ed.), Globalization and Patterns of Labour Resistance, London: Mansell, pp. 29-55.

'Transportation by agreement versus taxi service: what is the difference?' ('Kokkuleppevedu versus taksoteenus: mis neil ikkagi vahet on?') (2016), Business Sheet 12.12.2016, accessed 20 February 2018 at http://arileht.delfi.ee/news/uudised/kokkuleppevedu-versus-taksoteenusmis-neil-ikkagi-vahet-on?id=76573478.

Trumm, A. (2006), 'Recent developments of Estonia's social protection system', background paper prepared for the EU 8 Social Inclusion Study, World Bank, University of Tartu, Estonia.

Vahter, P. and J. Masso (2018), 'The contribution of multinationals to wage inequality: foreign ownership and the gender pay gap', Faculty of Economics and Business Administration Working Paper No. 106, University of Tartu, Estonia.

Visser, J. (2015), ICTWSS Database. Version 5.0, Amsterdam: Amsterdam Institute for Advanced Labour Studies (AIAS), October.

World Bank (2018), World Development Indicators database, accessed 31 January 2018 at http:// data.worldbank.org/indicator/NY.GDP.PCAP.PP.CD.

World Database of Diaspora Businesses and Professionals, accessed 22 December 2018 at https:// migrationdataportal.org/themes/diasporas.

World Development Indicators database, accessed 21 December 2018 at http://databank.world bank.org/data/reports.aspx?source=World-Development-Indicators. 